NBER WORKING PAPER SERIES

\title{
CAPE VERDE AND MOZAMBIQUE AS DEVELOPMENT SUCCESSES IN WEST AND SOUTHERN AFRICA
}

\author{
Jorge Braga de Macedo \\ Luís Brites Pereira
}

Working Paper 16552

http://www.nber.org/papers/w16552

\author{
NATIONAL BUREAU OF ECONOMIC RESEARCH \\ 1050 Massachusetts Avenue \\ Cambridge, MA 02138 \\ November 2010
}

We gratefully acknowledge support from the NBER Africa Project, without which our research would not have been possible. Earlier versions of this paper were presented at the 1st research conference in Cambridge, Wits Business School, Banco de Moçambique and Banco de Cabo Verde. We are thankful for comments and suggestions from participants and others, especially Sebastian Edwards, Jeff Frankel, Ernesto Gouveia Gove, John Luiz, Léonce Ndikumana, Joaquim Oliveira Martins, Francisco Queiró, Courtenay Sprague, José Tavares, Philip Havik and Augusto Nascimento. We also thank Manuel Cabral for presenting the first version at the pre-conference and OECD and João Farinha, José Mário Lopes, Fábio Santos, João Silva, Manuel Melo and Rita Borges for research assistance at CG\&G. The usual disclaimer applies. The views expressed herein are those of the authors and do not necessarily reflect the views of the National Bureau of Economic Research.

NBER working papers are circulated for discussion and comment purposes. They have not been peerreviewed or been subject to the review by the NBER Board of Directors that accompanies official NBER publications.

(C) 2010 by Jorge Braga de Macedo and Luís Brites Pereira. All rights reserved. Short sections of text, not to exceed two paragraphs, may be quoted without explicit permission provided that full credit, including $\odot$ notice, is given to the source. 
Cape Verde and Mozambique as Development Successes in West and Southern Africa Jorge Braga de Macedo and Luís Brites Pereira

NBER Working Paper No. 16552

November 2010

JEL No. F12,F13,F15,O11

\begin{abstract}
$\underline{\text { ABSTRACT }}$
This paper applies an interpretation of how globalization and governance $(G \& G)$ interact with convergence given Cape Verde and Mozambique's particular geographical and historical contexts. We hold that development success under globalization entails, necessarily but not exclusively, positive market perceptions regarding the orientation and predictability of policies as well as the accompanying institutional arrangements. As such, a positive G\&G interaction with respect to a comparator group can usefully be defined as success notwithstanding the inexistence of a universally applicable development model. In practical terms, we first identify macro-level policy and institutional combinations underpinning successful trade diversification (an indicator of globalization) and income convergence (an indicator of governance) in the sub-regions of West and Southern Africa. We then assess to what extent these combinations apply to both countries using an empirical analysis. We find that trade openness drives convergence and export diversification in Western Africa (which is becoming more diversified) while convergence is instead driven by economic and political freedoms in Southern Africa (which is becoming more specialized). Our empirical analysis is complemented by a case-study narrative of Cape Verde and Mozambique's long-term development, which allows us to also identify the following common drivers: moving towards a market economy; opening up to regional and global trade; increasing economic and political freedom; pursing macroeconomic stability and financial reputation; ensuring policy continuity (especially in the industrial and trade sectors) and focusing on human development (especially education and poverty reduction). Moreover, both countries reveal convergence compared to their sub-regional peers when looking at average GDP per capita and indicators of financial reputation and good governance. While these findings are insufficient to conclude that convergence will be sustained, the positive interaction between trade and financial globalization, on the one hand, and good governance and democracy, on the other, may help explain the observed diversity of the Portuguese-speaking African community, which includes three other countries (Angola, Guinea-Bissau and São Tomé e Príncipe).
\end{abstract}

Jorge Braga de Macedo

Universidade Nova de Lisboa

Faculty of Economics

Campus Campolide

1099-032 Lisbon, PORTUGAL

and NBER

jbmacedo@fe.unl.pt

Luís Brites Pereira

Center for Globalization and Governance (CG\&G)

Faculty of Economics

Universidade Nova de Lisboa (UNL)

Campus de Campolide

Lisbon 1099-032, PORTUGAL

lpereira@fe.unl.pW

An online appendix is available at:

http://www.nber.org/data-appendix/w16552 


\section{Introduction}

The global financial crisis turned the risk of excluding Africa economies from globalization into the certainty that poverty would worsen in most of them. Prior to this crisis, however, Africa accompanied the trend of sustained growth evidenced by emerging economies. Primarily due to the implementation of adequate structural and macroeconomic policies, growth was the strongest in decades (AEO, various issues; World Bank, 2009). In SubSaharan Africa, GDP growth increased from an average of $3.5 \%$ in 2000 to $5.7 \%$ by 2005 and Burkina Faso, Ethiopia, Mali, Mozambique, Tanzania, and Uganda, none of which is a major primary commodity producer, were able to post annual growth rates of over $5 \%$ in recent years (United Nations Africa Report, 2008).

Indeed, the expansion, diversification and deepening of trade and financial links between countries over several decades presented an unparalleled opportunity for some to raise their living standards and achieve the Millennium Development Goals (MDG). Notwithstanding Africa's improved economic situation, absolute poverty was still widespread when unprecedented energy and food price volatility brought worldwide expansion to a halt. Amidst dire global economic prospects, growth enhancing policies need to be assessed against progress on MDG, including the global partnership on development and prospects for international cooperation.

The evidence suggests that development success under globalization is less a question of relative resource endowments or geographical location than in past waves of globalization. Market perception of the orientation and predictability of national economic policies, and the accompanying institutional arrangements, have proved to be decisive everywhere. The Asian crises of the mid 1990s showed that economic openness must be accompanied by good public 
and private sector governance in order for countries to take full advantage of globalization. Examples of the former include sound macroeconomic policies, unfailing transparency, stable and rational incentive frameworks and robust financial systems coupled with effective supervisory and regulatory mechanisms.

Severe regulatory failures in developed countries, uncovered by the global crisis, confirmed that there is no universally applicable development model. Adequate governance responses to globalization thus become all the more important as globalization reduces national policy space and increases institutional and economic interdependence at various levels. At the same time, a more integrated global economic context necessarily demands greater policy and institutional coherence as well the knowledge required to implement the associated reforms and monitor them through effective peer review mechanisms.

To be sure, even among the highly integrated economies of the Eurozone, neither coherence nor knowledge were able to respond to the challenge posed by the global crisis. Nevertheless, regional economic cooperation remains a valid intermediate step toward the integration of developing countries into the world economy ${ }^{2}$. In addition to benefiting from regional economies of scale, their participation in reform programs within regional organizations also facilitates domestic authorities' work when implementing politically difficult measures. In the wake of the entry into force of the Lisbon treaty, the diverse perspectives of the $27 \mathrm{EU}$ member states have at last found an institutional framework. Even though the financial challenges remain daunting for several highly indebted member states, especially those inside the Eurozone, alternatives to cooperative responses consistent with regional integration have not been found. Indeed, the success of the EU attests to the advantages of among like-minded 
countries, where a combination of cultural proximity and mutual knowledge facilitated the deepening of the integration process from a free trade area to a single currency and the widening from the original six members through successive enlargements.

With respect to Africa, regional surveillance and peer pressure between the various partners have been set up and implemented over the last eight years: the African Peer Review Mechanism has involved 30 countries of which 12 have been examined ${ }^{3}$. Broader regional surveillance may help reduce the risks of macroeconomic slippage, resulting in a more stable, predictable environment - an essential factor for the private sector to flourish. Among Frenchspeaking countries in West and central African (so-called CFA), particularly those pegged to the euro, surveillance has been a driving force of economic policy coordination and integration even though in the 1980s enforcing the stability of the nominal exchange rate against the French franc led to unstable real effective exchange rates. The monetary allocation mechanism managed by the French Treasury kept the parity between the French franc and the CFA from 1948 until the devaluation of the latter in 1994, which led to a real depreciation in most members of the West African Monetary Union ${ }^{4}$. Their long experience with a monetary policy conducted by a strong institution that must preserve its independence vis-à-vis national governments has accustomed these countries to yielding some of their economic policy matters to a regional organization. In comparison to CFA common institutions, those in the Economic Community of West African States (ECOWAS, which includes Benin, Burkina Faso, Cape Verde, Côte d'Ivoire, Gambia, Ghana, Guinea, Guinea-Bissau, Liberia, Mali, Niger, Nigeria, Senegal, Sierra Leone and Togo), and the Southern African Development

\footnotetext{
${ }^{2}$ Macedo (2010) describes the implications of the crisis for international governance innovation and analyzes the peer review mechanism of the IMF for the G20 drawing on Niels Thygesen's label on peer pressure by proxy at IMF and by commitment at EU. See also Macedo (2008).

${ }^{3} 5$ were examined from July 2002 to 2007, 4 in 2008 and AEO (2009, p. 75) expected 6 but only 3 (including Mozambique) were carried out in 2009 (AEO, 2010, p. 72) plus Mauritius in the $13^{\text {th }}$ Forum in Kampala in late
} 
Community (SADC, which includes Angola, Botswana, Democratic Republic of Congo, Lesotho, Madagascar, Malawi, Mauritius, Mozambique, Namibia, Seychelles, South Africa, Swaziland, Tanzania, Zambia and Zimbabwe) have not yet been effective constituencies for reform. If the ECOWAS and SADC secretariats (in Abuja, Nigeria and Gabarone, Botswana respectively) were to cooperate with the Commission for the African Union, or the local offices of global organizations such as the United Nations, the International Monetary Fund and the World Bank, better interaction between globalization and governance would probably follow. With peer pressure, better information on the 15 partners in each one of the subregions and beyond would probably be available, facilitating business development and a more active role for civil society ${ }^{5}$.

The idea of producing usable information from within a cooperative framework is what we mean by "mutual knowledge", a term used in a declaration on MDG approved at the 2006 summit of the Community of Portuguese-speaking Countries (CPLP) held in Bissau ${ }^{6}$. Mutual knowledge is generally more limited and the data harder to compare outside of the OECD so that cooperation at the regional, sub-regional and international levels may neither produce knowledge of effective policies or institutions nor create conditions for their implementation. In fact, context-adjusted but also widely usable knowledge only results from identifying an appropriate constituency for each set of related problems and challenges. Reaching the MDG in 2015, for example, presupposed sustained pro-poor economic growth in addition to better

July. The effectiveness of mutual control devices reflects the extent to which cooperation overcomes collective action barriers and clears the ground for coherent reforms (Kanbur, 2004).

${ }^{4}$ Macedo (1986, p. 358) discusses the paradox of nominal stability and real instability in CFA countries.

${ }^{5}$ Some group averages below exclude Nigeria and South Africa because their GDP weight is too large. CPLP and NAFTA both have 1.4 members equivalent. See note 17 below.

${ }^{6}$ Aside from five African countries (Angola, Cape Verde, Guinea-Bissau, Mozambique, São Tomé e Príncipe), Brazil and Portugal are founding members, Timor Leste joined in 2001 while Equatorial Guinea, Mauritius and Senegal are associate members, the former having applied for full membership at the 2010 CPLP summit in Luanda. On CPLP, Macedo (2008) draws on a 2003 report for the OECD secretary general. Other useful references to work carried out along with the AEO report (produced since 2001) are in OECD (2003) and IICT (2007), the first comparative report on the 2006 Bissau declaration. 
governance and more aid, but there were no immediately available recipes on how to bring about a positive interaction between globalization and governance ${ }^{7}$. In other words, alternatives to both the "one size fit all” and "each case is unique” development approaches are urgently needed in a context which cannot draw upon existing experiences of institutional cooperation that foster mutual trust and generate mutual knowledge. Under these circumstances, the quest for African development successes remains a policy as well as a research priority, especially acute in Sub-Saharan Africa. In a nutshell, what is at stake for many African countries is how to ensure that current policy and institutional arrangements in the spheres of trade, finance, debt, investment and technology mutually reinforce each other in support of equitable, rapid and sustainable growth and development.

Against this background, we assess the extent to which Cape Verde and Mozambique may represent development successes in West and Southern Africa. Specifically, we seek to identify lessons for successful governance based on meaningful regional comparisons of Cape Verde and Mozambique's development experience. These lessons will also be drawn from the study of the complementarity of economic policies and accompanying institutional arrangements bearing on trade, finance and competitiveness. We realize the limitations that lack of data impose on this ambitious agenda but, in our view, identifying such lessons necessarily entails a broader scope of analysis than is usual. Moreover, by analyzing these countries in comparison with their neighbors we may also contribute towards greater mutual knowledge on economic development issues within CPLP and especially among the five PALOP.

\footnotetext{
${ }^{7}$ Bourguignon et al. (2008) underline the heterogeneity of country outcomes and the difficulty in finding patterns even in fragile states. This heterogeneity is no surprise: to "develop a global partnership for development”, the eighth MDG goal, reflects disappointment with the performance of developing countries which seemed to follow the policy recommendations of the "Washington consensus" during the 1990s. As governance improvements were not commensurate with the challenges of globalization, especially in what concerns financial markets, these countries faced recurrent financial crises which interrupted the long term convergence process.
} 
The emphasis on identifying the linkages between cultural, institutional and economic factors that fostered growth and development remains in this paper, organized as follows. Our interpretative framework, detailed in section 2, focuses on the interaction between globalization and governance, which may be positive or negative depending on the policies and accompanying institutional arrangements. Specifically, we hold that economic success under globalization entails, necessarily but not exclusively, positive market perceptions regarding outcomes such as export diversification and narrowing of the income gap with respect to the frontier. Success thus defined must, in turn, be underpinned by good governance and the freedoms that citizens and residents enjoy, which section 2 also discusses. Section 3, meanwhile, provides an historical and geographical perspective on Africa with comparisons in the sub-region as well as PALOP. Section 4 estimates the factors that determine export diversification, measured by the number equivalent Herfindahl index, and income growth strategies in comparison to sub-regional averages. Section 5 offers a narrative of long-term development in Cape Verde and Mozambique with respect to Foreign Trade and Economic Growth and Macroeconomic Policy and Financial Reputation. Once again, policy and institutional reforms provide context for good governance indicators and progress towards the MDG in a separate sub-section. The concluding section 6 raises the issue of whether cooperative governance and peer-review mechanisms are capable of sustaining African development successes when due account is taken of the diversity of experiences evident from ECOWAS, SADC and PALOP. 


\section{Interpreting how Globalization and Governance interact with Convergence}

Policy and institutional responses must necessarily change as the nature of globalization itself changes. Indeed, different waves of globalization (15th, 19th and 20th centuries, including the past decade) have interacted with different forms of governance responses. The interaction of globalization and governance is always context-specific, as defined by space (geography) and time (history). In the wave since the 1990s, the context is captured by convergence, often measure as the gap in per capita income relative to the frontier, and by democracy, often measured in terms of electoral competition and political participation but best understood by its constituent political and economic elements ${ }^{8}$. To enhance the quality of the democracy measure, we look at the index of political rights and of civil liberties published by Freedom House and at the indexes of economic freedom published by the Fraser Institute and the Heritage Foundation. The Freedom House Index defines democracy as a concept with attributes of political rights and civil liberties. Political rights include the right to vote, fair and free competition for the office, the presence of multiple parties and decentralized political power. Civil liberties refer to the existence of a free press, open public discussion and freedom of speech and assembly. The indices are ranked as follows:

\begin{tabular}{c|c}
\hline Political Rights and Civil Liberties & Economic Freedom \\
\hline 7 = maximum political rights & $10=$ maximum economic freedom \\
$1=$ minimum political rights & $0=$ minimum economic freedom \\
\hline
\end{tabular}

Since political rights and civil liberties are highly correlated, we replace them with the average of both (labeled prcl in Appendix 1). This composite indicator performed better in estimation and, in addition, it also has the advantage of being interpretable as an index of political

\footnotetext{
${ }^{8}$ Przeworski et al. (2000). Garoupa and Tavares (2009) show that higher income increases the survivability of democracy but they label a country as democratic if its governments are designated through elections in which more than one party competes and the winning party is not always the same. Persson and Tabellini (2006) introduce quality considerations through the concept of democratic capital. The age of democracy is labeled demage below.
} 
freedom, given that it captures its two mains constituent components. We also note that these measures must be used and interpreted with caution due to well known issues, most of which derive from the process of index construction itself, as pointed out by Oman and Arndt (2006) and Luiz (2008), and that Fedderkke et al. (2001) applied an improved method to South Africa. Below we draw on Luiz et al (2010) which have computed indexes of political and economic governance for Mozambique over the last 100 years.

These caveats should be borne in mind when reading some of our results. Countries are rated according to two 7-point scales, with 1 being the highest score for both scales. The sum of the points obtained in the scales classifies the country as free (2-5), partly free (6-10) or not free (11-14). The Freedom House Index dates from 1995 and includes data on ten components: Business Freedom, Trade Freedom, Fiscal Freedom, Government Spending, Monetary Freedom, Investment Freedom, Financial Freedom, Property Rights, Freedom from Corruption and Labor Freedom. Each component is measured by various indicators and is assigned a grade in a scale of 0 to 100. The ten component scores are then averaged to give an overall economic freedom score for each country. Although the definition of economic freedom is quite vague, and consequently measuring it lacks some precision, the index gains relevance worldwide as several studies reveal that there is an important relationship between economic freedom and positive social and economic values such as per capita income, economic growth rates, human development, democracy, the elimination of poverty, and environmental protection. Political rights are associated with free and fair elections for the executive and legislative branches of power, freedom to constitute political parties, freedom of association, independence from political, religion and military authorities, real possibilities of the change of power and other related aspects of the political system. Key elements of civil liberties include freedom of thought, religion, association, free press and respect for the rights 
of minorities. The concept of economic freedom is more difficult to define as it may relate only to private ownership, prices being determined by market forces, de jure and de facto entry and exit, efficient rule of law and official economic regulation guaranteeing competition or also include the financial freedom brought about by currency convertibility, stability of money value, central bank independence and deep financial markets. Furthermore, the widely used indexes include low taxes, a small share of government spending in GDP and flexible labor markets, and this appears to some as too extensive a definition of economic freedom. Once again the Luiz et al (2010) index for Mozambique avoids some of these pitfalls by distinguishing carefully between the rules of the game and their outcomes.

Macedo (2001) reports that trade openness reduces perceived corruption, even after correcting for its endogeneity, and claims that this was the way in which globalization improves governance, given highly significant historical control variables (e.g. protestant tradition, de facto democracy and OECD membership). Eichengreen and Leblang (2006) find a two-way interaction between democracy and globalization over the entire 1870-2000 period, distinguishing trade from financial openness but measuring democracy as a dichotomous variable. By introducing the extension of suffrage, for example, a negative interaction between democracy and debt default has been found for the period of the classical gold standard, with a more than proportional effect in capital-poor countries. At the time, parliamentary democracies were seen as sources of financial stability, to the extent that the checks and controls on the sovereign implied a greater ability to tax ${ }^{9}$. This contradicts the widespread view that the repression of democracy facilitated the operation of the pre-1914 international monetary system by making external adjustment easier during the second wave of globalization. Over the period 1970-2004, the different types of freedom interact differently

\footnotetext{
${ }^{9}$ Flandreau and Zummer (2004, p. 44) report an elasticity of 0.5 for the whole sample and of 1.3 for capital-poor countries.
} 
with the trade and financial globalization variables, and the interaction becomes more sensitive to regional context and to stages of national economic and institutional development ${ }^{10}$. Overall, allowing for the quality of democracy lowers the overall effect of globalization on democracy. One reason for this is the hypothesis that globalization's effects on democracy are mediated by slow-moving cultural values, which may, in turn, be associated with weaker constituencies for policy reform. This would imply that such variables might be accounted for by selecting groups of like-minded countries, like the OECD, for which the effect of globalization on freedoms would be stronger but this would neglect the convergence dimension, more visible on a global scale. Eichengreen and Leblang's (2006) also use a measure, “Age of Democracy” (labeled demage in Appendix 1), which counts for each country $i$ at time $t$ the number of uninterrupted year up to time $t$ that country $i$ has been democratic, i.e. its measures the length of time a country has been a democracy which is used in section 4 below. In addition, we employ data from the POLITY project, which codes countries' level of democracy as a function of institutional rules ${ }^{11}$. This project is also the source of information on constitutional age. POLITY defines constitutional change as occurring either when there is a political transition or when the absolute value of the score changes by at least three points. This allows for constitutional changes in both democracies and dictatorships.

Given these measures, the mutual relationship between globalization, governance and economic performance can be described along the following lines: a nation's resource endowments and its productivity determine how fast it can grow and the level of its economic well-being in terms of income per capita, both in absolute terms and relative to the income frontier. Feed-backs are possible: a richer country growing fast may invest more resources in scientific research and technology development and thus enjoy higher productivity levels than

\footnotetext{
${ }^{10}$ Section 4 below tests this result, reported in Macedo et al (2007), on ECOWAS and SADC in the form of the diversification-convergence interaction.
} 
a poorer, slow-growing economy. Through trade, capital flows or migration, globalization can influence the level of endowments available in an economy, or even, through international technology transfers, its productivity. Conversely a country's endowments of natural resources, labor, and capital, as well as its geographic location and efficiency of its production structures may determine how much it trades with the rest of the world in terms if goods, services and assets. Similarly, a country with good governance, namely a democratic state with high-quality institutions, effective corruption-free accountable bureaucracies, and a flourishing civil society may likely increase the quality, if not the quantity, of its most important endowment: its own people. Once more, cause and effect can be swapped: well-endowed countries may evolve towards democratic forms of government more easily, or, at least, they may afford investing more resources to build well-functioning institutions ${ }^{12}$.

While these interactions have been at the core of economics, this has not been the case of the issue addressed in this section ("how globalization and governance interact with convergence”), perhaps because of the interdisciplinary nature of globalization waves and of governance innovation - even when the distance to frontier is not as fundamental as it is for Africa. With respect to the relative strengths of the links between the current wave of globalization, the benchmark measure of freedoms and convergence, the empirical findings of Macedo et al (2007) reveal that political rights and civil liberties had a significant impact in the run-up to the third wave of globalization while feedbacks were somewhat weaker. As mentioned, further work is needed to understand the long-run dynamics and sustainability of this global system, in particular the mechanisms that could enforce or reinforce the expected positive effect of globalization on both convergence and freedoms. The particular interaction which involves democracy reflects historical, geographical, social, cultural, institutional and

\footnotetext{
${ }^{11}$ See http://www.systemicpeace.org/polity/polity4.htm
} 
economic factors and the method employed focuses on the economic aspect of this relationship. A complementary explanation of the interaction between globalization and governance can be based on the manner in which diversity, be it socio-cultural or economic is addressed by a given society ${ }^{13}$. This is taken up in the next section, with specific reference to the historical roots of CPLP in the first wave of globalization, associated with the Iberian maritime explorations of the 15 th century.

The available empirical evidence regarding the relationship between economic growth and political regime is weak or inconclusive, as discussed in Kohli (1986), Remmer (1990) and Przeworski and Limongi (1993). In the case of Africa, it is not possible to establish a clear link between political regime and economic growth according to Young (1998), amongst others. However, the poor economic performance of many of its authoritarian regimes during the 1980s suggests that these failed to promote economic growth. Indeed, Maravall (1995) notes that "a strong case can be made that economic reforms are more likely to succeed in a democratic political context. Political pluralism generates more and better information to use in economic decision making; moreover, democratic institutions may reduce the transaction costs of economic reforms, as well as restrict predation of public resources.” Looking at the Economic Freedom Index in Sub-Saharan Africa, we see that it is not only the poorest but also the most economically repressed world region: no country belong in the group of economically free countries, 7 are listed in the "mostly free group", 28 in the "mostly notfree” and 7 in the "repressed” group. More worrisomely, in the region, a decline in economic freedom is evident. Factors like corruption, excessive market regulation or the size of black

\footnotetext{
12 Bonaglia et al. (2009). Transport technology also changes costs, sometimes dramatically, making them very different from distance, as documented by Feyrery (2008).

${ }^{13}$ Indeed, one of the constants of human organization is the "absolute certainty that man will never be common, he will always de different, he will always give rise to diversity. And society, by managing this diversity, will manage prosperity and the creation of wealth” (Borges de Macedo 1996, p.194). The same holds true, of course, for the case of political diversity and whether peace or conflict ensues. The distinct processes of colonization of
} 
market are among the reasons for such a poor result. Using the variables listed in Appendix 1, results presented in section 4 suggest that, in both West and Southern Africa, economic convergence increases with political and economic freedom. Even though it warrants further investigation, the focus on the management of diversity as a determinant of positive G\&G interactions, especially that pertaining to policy and institutional reform, is especially necessary in connection with Africa. In this case, the knowledge thereabout is certainly less "mutual” than with respect to other regions, even outside of the OECD.

\section{History and Geography}

\subsection{World Regions}

Three “regions” (North America, EU, ASEAN + China, Korea, Japan) account for $1 / 4$ each of world GDP. Africa is in the "rest of the world" which includes over $1 \frac{1}{2}$ of world population, with other significant actors (Brazil, Russia, India) and salient regions (Middle East). Taking a global view should foster governance innovation, as dominant players have different strengths (Nye, 2002). Yet free rider problems prevent cooperation among abstract regions, especially those where there are no peer review mechanisms let alone a culture of cross-cutting intergovernmental cooperation, as seemed to be the case in the rest of the world significant actors and even in China, certainly before the creation of the Group of 20 (Macedo, 2010). In addition, around 70 "fragile states", most of which located in Africa, are very specific in their fragility (Bourguignon et al 2008).

Looking at the rest of the world, the share of world GDP accounted for by Africa plus South America combined doubled from 1820 to 1950 . The share remained constant since at around 10\% with North America and EU roughly equal to Asia (including Japan, Russia and Turkey), shares that are comparable to those prevailing in 1820. In 1950, however, North America and

the Americas is chosen to illustrate the importance of diversity and how it is managed as being a crucial 
EU accounted for $60 \%$ and Asia for $30 \%$. In terms of population Africa and South America combined have more than doubled their combined world share from $10 \%$ in 1820 to $15 \%$ in 1950 to $22 \%$ in 2003 while Asia has dropped from $3 / 4$ to $1 / 2$ and then rose again to $2 / 3$. In terms of GDP per capita, the relative shares are $1 / 2$ for Africa and South America combined and over 2/3 for Asia.

As emphasized in AEO (2010, box 2.2), strengthening the capacity of the national statistical systems is required for a results based management framework which in turn helps regional integration processes based on peer review ${ }^{14}$. The partnership known as PARIS21, hosted by the OECD, has been in operation since 1999 and on its tenth anniversary produced the Dakar declaration on the development of statistics ${ }^{15}$. Table 3.1 presents a statistical capacity indicator the five highest ranking countries and the five PALOP, noting that only three of the former are in Sub Saharan Africa. Indeed, the data drawn from the impressive database of the late Angus Maddison underscores this lack of knowledge. In year 1 there are only estimates of GDP for the five North African countries (Algeria, Egypt, Libya, Morocco and Tunisia), estimates of GDP for Ghana and South Africa begin in 1820 and for the remaining Sub-Saharan Africa countries in 1950. The share of Africa in world GDP falls from over 4\% to under 3\% in 1000, $1 \%$ in 1500 and around $.8 \%$ until 1820, when it begins to rise to about $1.2 \%$ in 1913 . In 1950 , when estimates for 34 new countries become available, the Africa share reaches under $4 \%$ again while Sub-Saharan Africa remains just under 3\%. Since then both shares have declined about 1pp of world GDP. As for the share of SSA in Africa, it rose from around 20\% until 34\% in 1913 and more than doubled to $3 / 4$ in 1950. Thereafter the Sub-Saharan share of Africa GDP

determinant of the interaction between economic and political organization in Macedo et al (2007).

${ }^{14}$ This objective also comprised part of the 'capacity building' initiatives in Africa undertaken by the World Bank during the 1990s. These entailed promoting technical expertise and data base construction, e.g. population census and socio-economic surveys.

${ }^{15}$ One year before, the Lisbon declaration on science for global development included the promotion of science and technology indicators for CPLP by CGIAR and other organizations: www.iict.pt, 
declined by more than 10 pp but West (=ECOWAS) and Southern (=SADC) shares in SubSaharan Africa remain at $40 \%$ and $30 \%$ respectively. The increase in population has been such that the relative stability in the share of world GDP implies a decline in GDP per capita of about 20 \%age points, from $42 \%$ of world GDP per capita in 1950 to $24 \%$ in 2003 . The corresponding figure for Sub-Saharan Africa is 18\%, forecast by IMF to rise to $21 \%$ in 2013.

The views of "development as self discovery" (Haussman and Rodrik, 2003) and the "ladder of competitiveness” (Causa and Cohen, 2006) suggest measures of competitiveness that go beyond relative unit labor costs (Branson et al 1987) and other refinements to the country narratives presented below. The main point, once again, is that diversity must be taken into account. While the impressive database used in Maddison (2007) has been criticized, it allows a "millennial" perspective on world regions and helps to avoid the pitfalls of a purely geographic approach ${ }^{16}$. Regions may be historical rather than geographical and interaction during the first wave of globalization and even the second did not involve nearly as many players as the current one. The complementarity between globalization and regional integration and the development paradigm based on mutual accountability first contained in the 2002 Monterrey declaration on MDG both suggest that in Africa interaction between globalization and governance has been weak. At the same time there is evidence that complementary reforms are not a "luxury" for developing countries (Macedo et al 2009c).

\subsection{Africa and Portuguese-speaking countries}

\subsubsection{The common historical legacy}

http://www.iict.pt/workshop/papers.asp including Giovaninni et al (2008) on statistics and good governance and Macedo (2008) on CPLP, drawing on IICT (2007) and work at OECD in note 7 above.

${ }^{16}$ Maddison (2001, p. 71-75) acknowledges the specificity of the Portuguese empire. Amaral (2009) revisits the Portuguese transition to democracy during the second wave of globalization. Macedo and Pereira (2007) were inspired to study the diversity of Portugal's and Portuguese speaking countries' responses to globalization by drawing on the concept of “differenciality” due to Borges de Macedo and discussed in Macedo et al. (2009a). 
The combination of Africa and South America is more obvious when the Atlantic side is considered. In effect, Mozambique was ruled from Goa in India during the first wave of globalization and the influence remained after the forced union with the Spanish Crown (1580-1640) but India suffered the competition from Brazil during the 1700s.

Contrary to what is sometimes believed, there was a fair amount of decentralization in the Portuguese empire even before the departure of the Crown Regent to Brazil in the wake of the first Napoleonic invasion in 1807 essentially moved the capital to the New World (Maxwell, 2004). The Crown remained in Rio de Janeiro after the congress of Vienna and the liberal revolution of the 1820s. Brazil remained an empire until 1890 and was therefore the sole monarchy in the Americas during most of the $19^{\text {th }}$ century. On the other side, the dispute between the two sons of the Regent led to the sole civil war in Portugal's history which lasted from the independence of Brazil in the early 1820s until the defeat of the absolutist brother Miguel in 1834. In spite of a successful stabilization in the 1850s when it joined the gold standard, Portugal suffered from the 1890 crisis and the currency became inconvertible until 1992 (Macedo et al. 1996). The transition of Brazil from Empire to Republic coincided with the financial crisis and the first default quickly followed the one of Portugal.

Similarly, the successive revolutions in 1910, 1918, 1926 and 1974 influenced the independence of the former African colonies, together with their own very diverse initial experiences with political and economic freedom. For example, the presumption that political freedom is incompatible with financial instead of complementary damages financial reputation considerably because when political rights decrease the capacity to tax, countries become serial defaulters; but Reinhart and Rogoff (2009) show that they are also capable of 
graduating ${ }^{17}$. More recently, the experience of Portugal with IMF adjustment programs may also be relevant to understand how countries like Cape Verde and Mozambique recovered financial reputation ${ }^{18}$.

Our motivation for studying these countries reflects previous attempts to contribute towards greater mutual knowledge within the CPLP with respect to the MDG (IICT, 2007; Macedo, 2008). Indeed, the Declaration on $M D G$ in CPLP (approved at the 2006 Bissau summit mentioned in the introduction) sees cooperative governance as capable of producing "mutual knowledge" among the eight member states based on the fact that the standards of appropriateness regarding policy and institutional reform may be less responsive to geography than to historical affinities. In spite of their geographical discontinuity, five Portuguesespeaking African countries formed the PALOP group in 1979, and held ten summits until 1992, when they signed the first Regional Indicative Program with the EU. With Timor-Leste joining in 2001, there are now six ACP Portuguese-speaking countries cooperating under the 10th European Development Fund. They signed a Memorandum of Understanding with the European Commission on the eve of the second Europe-Africa summit in late 2007, which extended to CPLP. Future activities, integrated into a multi-country approach, focus on democratic governance as a key determinant for poverty reduction ${ }^{19}$.

Moreover, it is widely recognized, within the development community, that both countries are actively seeking to overcome adverse developmental conditions, either due to geography (Cape Verde is a small island state devoid of natural resources) or history (Mozambique fought

\footnotetext{
${ }^{17}$ Tables 6.1-2-4-6, pp. 86-99 record one bankruptcy in Portugal from 1300 until 1812 (against 7 in Spain and 9 in France), six are recorded until 1890 (against 7 in Spain and zero in France and Brazil). Thus the share of years in default since independence or 1800 is similar in Brazil and Spain (Table 10.2, p. 149) while France stands out for the share in a banking crisis.
} 
a protracted civil war following independence). Cape Verde, for example, signed a five year contract in 2005 with the Millennium Challenge Corporation even though it was above the income per capita ceiling that determined eligibility. This was largely seen as an incentive for the country to continue its efforts on the development front. As expected, graduation to middle income status occurred in late 2007 and, at the suggestion of Luxemburg and Portugal, Cape Verde also signed a special partnership with the EU. Mozambique, meanwhile, was eligible for the Millennium Challenge Corporation since its inception in 2004.

Given Africa’s diversity, then, assessing development successes requires comparisons among partners in sub-regional organizations which include members with different cultural, historical and strategic affinities. ECOWAS was established in 1975 and SADC in 1980, and each now includes 15 countries, as listed above. The experience of Cape Verde and Mozambique is systematically compared to the ECOWAS and SADC average but also to SubSaharan Africa and PALOP. Table 3.2 summarizes the various sizes relevant to the comparisons in the next section, including comparisons between PALOP and CPLP and the share of both Africa and its Sub-Saharan part in the world in terms of GDP, population and GDP per capita ${ }^{20}$.

Common features in the five PALOP may reflect institutions preceding independence, in spite of very diverse experiences with political and economic freedom since then. Like Portugal during the first half of the $19^{\text {th }}$ century and again after the 1890 bankruptcy, financial reputation suffers when political rights decrease the capacity to tax. Like Portugal since 1979,

\footnotetext{
${ }^{18}$ Bliss and Macedo (1990) and Macedo (2009). Using Reinhart and Rogoff (2009) again, the change from 1979 to 2008 in the credit rating from Institutional Investor (Table 17.2, p. 285) is 19 points in Spain and Greece but 33 in Portugal, reaching 90, 85 and 81 respectively in 2008 (Table 17.2, p. 285).

${ }^{19}$ In relation to poverty reduction, see Paul Collier (2007) and especially Collier and Gunning (1999).

${ }^{20}$ The weight of Brazil is of course overwhelming and the four micro states never rise above 25 basis points of GDP in 1990 international dollars, the number equivalent of NAFTA, as indicated in note 5 above.
} 
some PALOP have been able to improve their credit rating through appropriate policies. It is therefore useful to preface the estimation of diversification-convergence regimes in West and Southern Africa with a reference to the contrasting political culture of Cape Verde and Mozambique.

The comparative evolution of GDP per capita in 1990 international dollars from 1950 until 2006 for PALOP and Sub-Saharan Africa averages shows a more volatile growth pattern for the former group with more pronounced growth in the 1950s and the last decade (Figure 3.1). This reflects civil wars following independence especially in Angola and Mozambique, the two larger economies. In spite of the common colonial history, the pattern of each one of the five PALOP is very specific: Figures 3.2a and b compare GDP per capita in Cape Verde and Mozambique to the respective sub-regional averages from over six decades ${ }^{21}$. According to AEO, Cape Verde, São Tomé e Príncipe, Mozambique, Guinea-Bissau, Angola is the ranking which applies to export diversification, political and economic freedom as well as corruption perception in PALOP: Tables 3.3 through 3.5 present the latest data available and will be detailed below for the first and third ranked.

In regional terms, current SADC countries showed greater export diversification than those of ECOWAS or the average for Sub-Saharan Africa since 1960, as measured by the number equivalent Herfindahl index. Export diversification in Mozambique and Cape Verde also tend to be higher than the Sub-Saharan Africa average but the number equivalent varies a great deal (Table 3.6): data for Cape Verde begins in 1976 and in Mozambique recent large scale investments determined both a strong increase in the exports and an increase in specialization. The decrease in export diversification in Mozambique followed a strong expansion of one

\footnotetext{
${ }^{21}$ The source is Maddison database which contains two outliers for GDP of Cape Verde in million GK\$. The series is 1990: 430; 1991: 283; 1992: 231; 1993: 434 and the correction was interpolating the two outliers, so that GDP per capita growth is smoothed during those years. Frankel (2010) presents governance rankings alongside GDP per capita figures consistent with the ranking in the text.
} 
single industrial product rather than from a decrease in the exports of other products. In all six governance indicators reported in Table 3.7, Cape Verde scores higher than the ECOWAS average and Mozambique performs better than the SADC average in three of them, as detailed in section 5.2 below.

(Insert Tables 3.2 through 3.7. and Figure 3.1 through 3.2b here)

Comparing GDP growth rates of the both countries since 1950 shows a growth differential of almost 2\% for Cape Verde relative to ECOWAS whereas Mozambique growth is slightly below that of SADC. The decade averages show the greater volatility of Mozambique's output with two decades of negative growth, whereas in Cape Verde there was a negative differential of $4 \mathrm{pp}$ in the 1970s. While this difference has roots in the colonial period, the pattern was reinforced after independence, as described next.

\subsubsection{Cape Verde}

After achieving independence in 1975, Cape Verde was governed under a one-party system that pursued an inward-looking, activist development program based on central planning and an economically dominant public sector, particularly in banking, transportation, insurance and energy (IMF, 1999). Motivated by the need to overcome the colonial legacy while minimizing the risk of possible political resistance, the new government adopted a protectionist trade regime and controlled the economy directly. As consequence, there was limited scope for competitive export promotion and foreign direct investment was also discouraged: the resulting loss of competitiveness and the reduction of foreign direct investment became major constraints for sustainable long-run growth (Lourenço and Foy, 2003). As of 1988, a wideranging program of reforms aimed at trade liberalization and privatization reduced the government's role to essentially that of building badly needed infrastructure but the country 
was governed under a one-party system until 1990. Popular dissatisfaction led to free legislative and presidential elections and a constitutional amendment establishing a multi-party system in 1991. Economic reforms gathered further pace after the country held free elections. The Movement for Democracy (MPD) took power away from the African Party for the Independence of Cape Verde (PAICV) that had led Cape Verde since independence and amended the 1980 constitution to allow for a multiparty democracy. The MPD government continued the economic reforms started by its predecessor, especially those pertaining to financial and foreign exchange markets. Since the adoption of this regime, there have been three legislative elections with results considered to be non-fraudulent and two orderly changes in government.

Indeed, the fact that democratic governance has taken root is widely recognized by various governance indicators. The 2008 Ibrahim Index of African Governance ranks Cape Verde second overall in a sample comprising 48 Sub-Saharan countries. Cape Verde has good results in terms of safety and security, sustainable economic opportunity, participation and human rights and human development when compared to its peers, with safety and security obtaining the highest score and sustainable economic opportunity the lowest. Data from the Freedom House Index also confirms the good results of Cape Verde in terms of political stability: Cape Verde is defined as free, obtaining the highest scores (1) for political rights and civil liberties. The presence of "creolisation / métissage” from the first settlers helped promote the view of peace and development. This "peace culture" has been reinforced by the absence of civil strife and by the impressive performance in terms of MDG, reflecting political stability, security, good governance and functioning democratic institutions. The insular nation, without natural resources, has become an example of best practice: its neutrality in the region lead to its role of mediator - good reputation (“donors’ darling”), leadership in UN reform and using culture 
as a means of promoting tourism and development ${ }^{22}$.

\subsubsection{Mozambique}

Three different governance regimes can be identified: the pre-independence period (19601974), the post-independence period, which was marked by civil war (1975-1992) and the post-peace accord period (1993 onwards) ${ }^{23}$. Following independence, economic growth was stunted by a civil war estimated to have killed up to one million people. It is also affected by the Marxist-socialist ideology espoused by the governments in the immediate postindependence period. Prior to independence, there was significant public investment in infrastructure and also expenditures in health and education during the period 1960-73, which contributed strongly to Mozambique’s growth. In agricultural sector, it was generally true that large private farms performed better than smaller ones, and therefore accounted for the bulk of agricultural output. However, the post-independence economy was very much governmentcontrolled. By 1984, for example, more than half of all registered firms were state-owned. Not unexpectedly, the development of a market-economy was severely hampered, which impacted negatively on growth. During the 1980’s, Mozambique began gradually moving away from a centrally planned economy, e.g. price controls on vegetables and fruits were removed. Another example is the enactment of 1987 Economic Rehabilitation Program, which led to a strong shift toward market-based economic policies and the pursuit of structural reforms. These included the stabilization of the exchange rate, trade liberalization, extensive privatizations

\footnotetext{
22 The argument in Santos (2010) is based on a Ph.D. dissertation in peace studies a la Galtung (1996) where she analyzes the thought of Amilcar Cabral $(1975,1999)$ who led the liberation struggle of Cape Verde and Guinea Bissau and influenced leaders of several other colonies especially Angola (Cabral, 1995, 1987; Andrade, 1978). Surprisingly she leaves out Cardoso (1986) which is seen as very influential. Another useful reference is the acceptance speech of an honorary doctorate from the Technical University of Lisbon on 26 May by the current Head of State (Pires, 2010). However, Lourenço and Foy (2003) claim that the resulting loss of competitiveness and the reduction of foreign direct investment became major constraints for sustainable long-run growth during this period.

${ }^{23}$ Tibana (2003) performs a trend and a business cycle analysis in the post-peace accord period, pointing out different growth behaviours within it. Such periods are: an immediate post-war recuperation (1992-94), a period of slow growth and heavy infrastructure investment (1995-2000) and a strong-growth period (2000-02).
} 
and tariff and financial sector reforms. However, it was only after the consolidation of peace that any significant improvements had the opportunity to occur. A contributing factor to a quick post-conflict development was the UN-led program of exchanging guns for vouchers

which allowed an easier transition from war to peace. While it was soon discontinued because of difficulties in redeeming these vouchers, the program remains a success in confidence building. Following the signing of the 1992 Rome treaty, a new constitution was adopted that allowed for democratic elections and progress further toward a market-economy. A prosperous transition after the peace accord allows Mozambique’s economic performance to be compared to the best performers in the sub-region, namely Mauritius and South Africa. Nevertheless, the rehabilitation and political transition took a few years, before the mega-projects such as the MOZAL aluminum smelter plant and the Witbank highway, connecting Mozambique and South Africa were implemented in 1996-99, leading to the take-off of growth after 2000. According to Tibana (2003), economic activity increased from 1991 until 1995 but slowed down during the preparation and implementation of the mega-projects that came to define the country's export behavior and high-rates of economic growth. Over the past decade, Mozambique has again become one of the attractive economies in the sub-region, as revealed by Luiz et al (2010) from where Figure 3.3 is reproduced.

\section{Analyzing the Convergence-Diversification Relationship}

In this section, we study the two-way relationship between trade diversification and income convergence motivated by the insights provided by our interpretative framework and the empirical finding that economic development, measured by per capita income, entails more diversification. The general observation is that economies become more diversified as incomes increase before reaching a turning point, which Imbs and Wacziarg (2003) estimate to be around USD 9000 per capita, beyond which they become less diversified, a stage not yet 
observed in the Sub-Saharan Africa database used by Cabral and Veiga (2010) which includes data disaggregated at five different levels, according to the categories of the SITC trade data $(\operatorname{Rev} 2)^{24}$. In other words, development occurs when a country learns how to do new things and focus on those that it already does well, such as producing new goods, choosing promising export markets, upgrading product quality and moving into services exports. We note, in passing, that another strand of literature argues that diversification should focus on exporting more sophisticated products as these entail higher productivity levels conducive to higher growth levels (e.g. Hausmann et al, 2007). In this case, a country becomes what it exports, i.e. countries converge to the level of income implied by their exports ${ }^{25}$. The common point in both approaches, however, is that product development is undoubtedly an important engine of growth for developing countries.

The study of how economic policy and institutional variables promote or limit the capability of countries to pursue successful export diversification and sophistication strategies serves as background for the identification of the factors that determined the success obtained by Cape Verde and Mozambique. Using regression analysis in a panel of 48 countries and 45 years, Cabral and Veiga (2010) establish that the stage of development and the economy's size are positively correlated with export diversification, and that economies with larger GDPs or populations also have higher export sophistication levels. Moreover, both diversification and sophistication are promoted by trade integration, efforts to reduce transport costs as well as improvements in institutional, political and educational factors.

\footnotetext{
${ }^{24}$ Cabral and Veiga (2010) present mostly results with more disaggregated data, since the results tend to be stronger and more accurate than when the 1 and 2 digit categories are chosen. They add in note 12 on page 15 that the results remain broadly similar independently of the level of disaggregation used.

${ }^{25}$ The issue of export sophistication is analyzed in Cabral and Veiga (2010) and note 16 above.
} 
When used to explain export diversification, 19 out of the 26 governance variables presented significant positive signs. The results were particularly robust for the variables reflecting government accountability, respect for the rule of law, political stability, effectiveness, and control of corruption (Table 3.7 above). In export sophistication regressions, 15 out of 26 variables are not statistically significant but "transparency”, “accountability” and "control of corruption in the public sector”, “debt policy and fiscal policy rating”, “economic management cluster average” and "policies for social inclusion” have a positive association.

Since 1960, the average of current SADC countries showed greater export diversification, as measured by the number equivalent Herfindahl index, than ECOWAS or Sub-Saharan Africa (Cabral and Veiga, 2010, graph 8). It is seen that improving the education standards of the labor force (measured by the share of GDP spent in education or the World Bank index about “building human resources”) is associated with export diversification. Moreover, lower levels of education are associated positively with diversification while higher levels are associated with export sophistication. While equations in which diversification and sophistication were used to explain GDP growth suggested a positive but not robust relationship, higher diversification and sophistication were associated to lower variation in the rate of growth of both GDP and per capita income. The estimated coefficients suggest that a $10 \%$ per cent increase in diversification leads to a 4,6\% decrease in the variation of GDP growth and to a $4,4 \%$ reduction of income per capita variability. Similar results were obtained for sophistication, with country fixed effects model suggesting that increasing sophistication may have a stronger marginal effect in decreasing economic instability than diversification in SubSaharan Africa. In addition, higher diversification and sophistication are associated with lower infant mortality and the higher life expectancy. The estimated coefficients are robust and the impact independent of that of diversification and sophistication on income per capita, which is 
all the more relevant as higher average income does not necessarily translate in better life for the majority of the population.

Export diversification in Mozambique and Cape Verde also tend to be higher than the SubSaharan Africa average but the number equivalent varies a great deal (Cabral and Veiga, 2010 graph 9): data for Cape Verde begins in 1976 and in Mozambique recent large scale investments determined both a strong increase in the exports and an increase in specialization. The decrease in export diversification in Mozambique followed a strong expansion of one single industrial product rather than from a decrease in the exports of other products. Figures 4.1a and b, second panel show the comparative pattern of the number equivalent for ECOWAS and SADC countries respectively while Figures $4.2 \mathrm{a}$ and b below, third panel compare Cape Verde and Mozambique to the group average.

Export diversification and sophistication in Cape Verde and Mozambique relative to the average in Sub-Saharan Africa are shown in Cabral and Veiga (2010, graphs 9 and 10). With respect to diversification, Cape Verde ranks higher, whereas Mozambique has improved sophistication. In this regard, Cape Verde is close to 6000 while ECOWAS is around 5000, even though in the early nineties it decreases to 3000 and 2000 respectively. Mozambique with a lower sophistication than SADC during the nineties but its sophistication increased sharply since 2000 overcoming that of SADC. The average annual change in the number equivalent for 5 year periods in Cape Verde and ECOWAS shows that, from 1976 to 2005, a new good was being exported by Cape Verde approximately every five and a half years $(1 / 0.18=5.55)$. In Mozambique there was significant diversification up to the late seventies while SADC was actually concentrating. However, from the eighties on, concentration was large, especially in 
the early nineties and between 2001 and 2005. During the latter period, on average, every two years a product stopped being exported (1/0.48).

With this in mind, in this section we seek to identify macro-level policy and institutional combinations underpinning successful export diversification and economic convergence in ECOWAS and SADC. Just as important, we also expect to establish context-based objective metrics that will subsequently allows us to better assess the relative performance of Cape Verde and Mozambique on both counts in conjunction with evidence of a case-study nature. This indirect approach to study trade-related development success in these two countries is unavoidable as the severe lack of data prevents us from analyzing them empirically. Our study covers the period 1960-2004 and uses annual data obtained from various sources (see Appendix 1 for full details, including summary statistics, on variables used in our estimations). Before presenting qualitative results from the econometric analysis, a snapshot of eight indicators used in the empirical analysis can be seen in Appendix 2 Figures 1a, b, for each one of the member countries in ECOWAS and SADC respectively. Panels 1 through 8 report the following variables, Convergence: Income Gap to Frontier, Country and U.S. GDP per capita, constant 2000 USD; Diversification: Number Equivalent Index of exports at 1,2,3,4,5 digit SITC; Monetary stability: Inflation in consumer prices; Fiscal sustainability: Government Surplus/Deficit \% GDP; Trade openness: Exports plus Import \% GDP; Political Freedom; Economic Freedom; Life expectancy at birth. We also depict the relation between diversification and convergence for Cape Verde and Mozambique over time and also with respect to their respective regional averages. Figures 4.1a, b compare convergence and diversification indicators in panels 1 through 3 and show the time series of Income Gap and Number Equivalent for Cape Verde and ECOWAS, Mozambique and SADC in panels 2 and 3 respectively. Figures $4.2 \mathrm{a}$, b show the relation between same variables in terms of the raw data 
and country means in panels 1 and 2 respectively. The raw data, country means and time means for the relation between Income Gap and Government Deficit is shown in Figures 4.3a, b panels 1 through 3 and the relation between Economic and Political Freedom in Figures 4.4a, b panels 1 and 2. Account is taken of the different performances by defining "high" and "low" regimes in terms of the variables of interest and Figures 4.4a, b panel 3 compare the relation between Economic and Political Freedom for the full sample and the two regimes. Figures 4.5a, b panels 2 through 7 present the indicators in Appendix Figures 1a, b, panels 2 through 7, while growth in GDP per capita replaces the distance to frontier in Figures 4.5a, b panel 1. The insights obtained from these graph, as well those from the LOWESS plots (Figures 4.2a, b - 4.4 a, b) will help us to better understand and interpret our results, especially with respect to variables identified as being highly significant in our econometric analysis ${ }^{26}$.

The first LOWESS plot clearly depicts the expected (negative) relation between diversification and convergence when using the country means, i.e. mean ygap and mean neq5 for each country (Figure 4.2a, b). When all observations are taken into account, the same is true for SADC but there is no discernible relation between the two variables for ECOWAS. It is also clear that the strong negative relation exhibited by SADC is largely attributable to South Africa's high level of diversification. Once we exclude South Africa from the sample, we observe that the relation in now ambiguous and not dissimilar to that of ECOWAS. Regarding government deficits, we observe that lower budget deficits are associated with increased convergence, especially when they are less than 6\% of GDP for ECOWAS and around $8 \%$ for SADC (Figure 4.3a, b). As for the relation between political and economic

\footnotetext{
${ }^{26}$ LOWESS, or locally weighted scatter plot smoothing, is a method that fits simple regression models to localized subsets of the data. The objective is to build up a function that describes, point by point, the deterministic part of the data's variability. For further details, see Cleveland's (1979) seminal contribution and also subsequent developments by Cleveland and Devlin (1988). Note that we only present those LOWESS plots in which there is clear and interpretable relationship between the variables under consideration. The others are available from the authors upon request.
} 
freedoms, it is clearly positive in both regions but more so for SADC based on the visual inspection of the LOWESS plot obtained using all observations (Figure 4.4a, b). When one uses country averages instead, we see that there is an unequivocal positive relation between freedoms in SADC (Figure 4.4b panel 2) while it is somewhat "u-shaped" in ECOWAS, (Figure 4.4a panel 2) which possibly reflects the fact that the region aggregates countries with dissimilar characteristics on this score.

Turning to our empirical analysis, we adopt a system equation approach mainly because we believe that it is better suited to model interdependence between variables. We also seek to address the problem of endogeneity due to simultaneity bias and so make use of the standard Three-Stage Least Square method (3SLS). This method incorporates uses all the information provided by the exogenous right-hand-side (RHS) variables to instrument the endogenous (LHS) left-hand-side variables. As such, it avoids the potential pitfall of having to find "good" instruments within a single equation context. Notwithstanding this advantage, we recognize that 3SLS may be more sensitive to the existence of spurious correlations or multicollinearities among the regressors in one equation, thereby "contaminating" the remaining equations. In our sample, this does not seem to be an issue, however. In order to assess the robustness our method, we also estimated the diversification-convergence relation using alternative estimation techniques, namely Ordinary Least Squares (OLS) and Two-Stage Least Square (2SLS). Since the results obtained are broadly consistent Tables 4.1a and b present the 3SLS results while the others are in Appendix 2.

As for our dependent variables, we measure the distance of a country’s GDP per capita $\left(y p c_{i t}\right)$ compared to that of the United States $\left(y p c_{U S A, t}\right)$ in order to capture economic convergence. Specifically, the income gap is calculated as $y g a p_{i t}=1-\left(y p c_{i t} / y p c_{U S A, t}\right)$, which implies that 
the income gap narrows as $y p c_{i t}$ increases. We measure export diversification using the number equivalent index (neq $5_{i t}$ ), which is calculated as the inverse of the Herfindahl Index (5-digits, SITC rev.2). Together with additional control variables, we expect these two variables to be a meaningful characterization of each country's diversification-convergence regime, which will be affected by the interaction between policy and institutional variables. Accordingly, we specify the following two-equation simultaneous system for our analysis:

$$
\begin{aligned}
& \text { (1) } \operatorname{ygap}_{i t}=\alpha_{1} \cdot \text { neq }_{i t}+\delta_{1 \cdot}\left(\text { Policy }_{i t}\right)+\beta_{1 \cdot\left(\text { Institutions }_{i t}\right)}+\gamma_{1} \cdot Z_{1 i t}+\varepsilon_{1 \cdot i t} \\
& \text { (2) } \text { neq }_{i t}=\alpha_{2} \cdot \text { ygap }_{i t}+\delta_{2 \cdot}\left(\text { Policy }_{i t}\right)+\beta_{2 \cdot}\left(\text { Institutions }_{i t}\right)+\gamma_{2} \cdot Z_{2 i t}+\varepsilon_{2 \cdot i t}
\end{aligned}
$$

where $i=1, \ldots, N$ countries and $t=1960-2004$. For each country, Policy ${ }_{i t}$ and Institutions $s_{i t}$ respectively represent economic policy variables (inflation, government deficit and degree of openness) and institutional ones (political and economic freedom, age of constitution, age of democracy, number of prior transitions to dictatorship, amongst others). $\left\{Z_{i}\right\}$ denotes a set of control variables (see appendix 1) where the economic variables (such as capital and labor endowments) are used together with geographic variables (such as distance or landlockedness). Our initial estimation process revealed that the inclusion of certain key variables of interest, such as the real effective exchange rate and measures of exchange market pressure (EMP), dramatically reduced the number of observations that were available to be used in our models. We subsequently dropped these variables from our analysis but evidence on conditional EMP is presented in the next section.

Regarding our estimation strategy, we first estimate the log-log equivalent of equations (1) and (2) for each region in order to identify the determinants of diversification and convergence at the regional level. Then, we re-estimate these two equations for regional sub-samples that capture two different diversification-convergence scenarios. The first sub-sample, denoted as 
the HIGH-regime, comprises countries that simultaneously exhibit high diversification and high convergence while the second, the LOW-regime, comprises those that exhibit the opposite combination. We expect that this strategy will allow us to highlight differences and commonalities in performance across regimes and regions.

We identify the criteria used to divide the sample from the visual inspection of the partial relation between income gap and number equivalent index averages (see Figures 4.3a, b, bottom panel). We define HIGH-regime as those observations satisfying the condition ygap < $0.945 \&$ \& $e 5>4.5\}$ and LOW-regime as those where $\{$ ygap $>=0.945 \&$ \&eq $5<=4.5\}$ in the case of ECOWAS. In effect, we are isolating the upper-left and bottom-right quadrants for further analysis. Moreover, we identify Senegal as potential regional benchmark with which to compare Cape Verde given its high intra-regional diversification-convergence combination. We adopt the same conditions for SADC to facilitate inter-regional comparisons and identify Mauritius and South Africa as potential benchmarks. Estimation results are given in Table 4.1a, b which includes both the full sample and two sub-samples for ease of comparison.

(Insert Table $4.1 \mathrm{a}$, b here)

With respect to ECOWAS, we find a two-way relationship between convergence and diversification but only under the HIGH-regime. Moreover, the estimated coefficient of the impact of diversification on convergence is relatively and highly significant $(-0.646$ at $1 \%$ level). Under the LOW-regime, the relation is only 1-way as more convergence always increases diversification but not the other way round. For the region as whole, diversification increases with more convergence but more diversification actually leads to less convergence. This result is unexpected but plausible given the ambiguous relationship between these two variables in ECOWAS, as depicted in Figure 4.3a (top panel), and non-linearities that characterize many of the partial relations between variables. The impact of convergence on 
diversification is also weaker when compared to the HIGH-regime as the estimated coefficient is about half as large (-0.398 vs. -0.751). Together, these results appear to indicate that a critical level of diversification is needed before one observes a two-way relationship, ceteris paribus.

For SADC, the two-way relationship between convergence and diversification occurs under the HIGH-regime and, significantly, also for the full sample. These finding contrasts with the one obtained for ECOWAS, where only the HIGH-regime exhibited such behavior. It is probably due to the influence that highly diversified countries such as South Africa and, perhaps to a lesser extent, Mauritius, exert on the region ${ }^{27}$. It may also be due to the fact that SADC is almost $70 \%$ more diversified than ECOWAS (6.47 vs 3.83 mean neq5 as reported in table A1.1). In contrast, the two-way relation is positive under the LOW-regime: more diversification leads to less convergence and less convergence leads to more diversification. This result implies that SADC countries experiencing low levels of diversification may well need to specialize in order to ensure more convergence. This could be the rationale for Mozambique's move towards lower diversification, albeit accompanied by higher GDP per capita growth rates, as discussed below.

(Insert Figure 4.6a, b here)

In order to better interpret our empirical findings, as well as to highlight possible differences and commonalities in performance, we also look at how key model variables differ across HIGH and LOW regimes for each country (see Figure 4.6a, b). Note that we use each country's of GDP per capita growth rate in lieu of its rate of convergence to the income frontier as the latter measure would also reflect changes in the United States' GDP per capita.

\footnotetext{
${ }^{27}$ Indeed, our initial OLS and 2SLS scoping estimations indicated that the determinants of diversification and convergence are broadly similar for ECOWAS and SADC when South Africa is excluded from the latter sample. These results are available from the authors upon request.
} 
Interestingly, almost all of the highly diversified countries in ECOWAS register negative GDP per capita growth rates with the exception of Cape Verde. Indeed, it is striking that Cape Verde exhibits not only the highest GDP per capita growth rate in ECOWAS but also one that is fairly consistent across both regimes. This finding accords with our findings in section 3 and is also reflected in our estimates, as the Cape Verde dummy contributes towards more convergence under the full sample. Moreover, its effect for the Cape Verde dummy is almost on par as that of the benchmark. Note also that while Cape Verde is not as diversified as Senegal, it has increased its number equivalent appreciably between regimes as a result of its positive diversification trend over time.

For SADC, GDP per capita growth rates are positive under the HIGH-regime with the exception of Madagascar, Mozambique and Zimbabwe. In the case of Mozambique, however, the move towards less diversification is accompanied by positive GDP per capita growth, which appears to be a notable reversal of fortunes. Indeed, Mozambique’s growth under the LOW-regime compares very favorably with that of Mauritius, which is highly diversified and so has no observations falling in the LOW-regime sub sample (see Figure 4.5b).

Turning to the other policy variables, we find that more inflation leads to more convergence under the full-sample and LOW-regime. In the case of the latter, more inflation also leads to diversification as does a higher budget deficit. This result could mean that increased diversification is associated with less macroeconomic stability but this intuition needs to be confirmed. For the HIGH-regime, we find no relation between inflation and diversification while increased budget deficits lead to less diversification and have no effect on convergence. A greater degree of openness leads to less diversification and more convergence under this regime and has no impact whatsoever on the others. Our reading of Figure 4.5a reinforces 
these findings: inflation is generally lower under the HIGH-regime for countries experiencing both regimes (with the exception of Ivory Coast) while government deficits are higher but only moderately so in most cases and always less than 10\% of GDP. For Cape Verde, the result of government deficit consolidation as diversification increased is very clear as is the dramatic lowering of its inflation rate. Diversification coupled with convergence also appears to go hand in hand with an average degree of openness in the range of $60-80 \%$ of GDP based on Ivory Coast, Cape Verde and Senegal's performance on this score.

The results obtained for policy variables in SADC differ from those in ECOWAS when compared on a sample by sample basis. We find that more inflation leads to less convergence and less diversification under the LOW-regime, as does greater openness. Greater openness is also associated with less diversification in the full sample. Increased government deficits, lead to more convergence and less diversification for the same sample but increase diversification under the HIGH-regime. Our reading of Figure 4.5b is that more inflation, larger budget deficits and being less open are a greater concern for countries under the LOW-regime. Regarding Mozambique, the shift towards less diversification is accompanied by lower inflation but also higher deficits and it appears that there is scope for it to increase its degree of openness. With the exception of the sole effect mentioned above, we note that the effect of policy variables is not as pronounced under the HIGH-regime as in the others, which we take to be a sign of policy credibility.

As for the institutional variables, convergence increases as political and economic freedom increases in ECOWAS. Also, there is more convergence as the age of democracy increases, and this holds true for the LOW-regime. However, an increase in the number of democracies in the system unexpectedly reduces convergence. Under the HIGH-regime, diversification 
increases with more political and more economic freedom. In the other two cases, diversification is associated with more economic freedom only. Indeed, we observe that the effect of economic freedom is pervasive across all samples and its effect is largest precisely under the HIGH-regime. In the full sample, being an older democracy also leads to less diversification as do a larger number of prior transitions to dictatorship in the LOW-regime. There is also more convergence under an English legal tradition. While these results are interesting, they clearly need to be further explored ${ }^{28}$.

For now, we take away the insight that a positive relation must exist between economic and political freedoms, which may have to exceed some critical threshold, in order for there to be an environment conducive to convergence (full sample). In addition, economic freedom may be a necessary, but not sufficient, condition to underpin successful diversification in ECOWAS. The insight applies to SADC: an increase in both political and economic freedoms increases convergence in both the LOW and HIGH regimes. This does not happen in the full sample, possibly because of a composition effect (we have the combined effect of two opposing effects associated with more economic freedom, which leads to more diversification under the LOW-sample and less under the HIGH). Moreover, an increase in both freedoms increases diversification under the LOW-regime but has the opposite effect under the HIGH. Here again, the full sample exhibits mixed results. Even though this is not the main focus of analysis in this section, most control variables display the expected signs ${ }^{29}$. Additional insights against which to interpret both countries’ performance with respect to political and economic governance and the convergence-diversification relationship relative to their sub-regional partners is provided in the next section.

\footnotetext{
${ }^{28}$ This task requires a better understanding of how freedoms interact with one another and how they relate to alternative legal, political and constitutional arrangements, a task initiated in Macedo et al (2007).

${ }^{29}$ For example, more capital and more oil both lead to more convergence while landlockedness has the opposite effect in ECOWAS. On the other hand, total labor force and population density, have unexpected signs.
} 


\section{Comparative Description of Cape Verde and Mozambique}

We seek to embed the insights from the estimation of diversification convergence regimes to successful development experiences in Cape Verde and Mozambique into a comparative description of the broad dimensions of economic growth and foreign trade on the one hand and macroeconomic policy and financial reputation on the other. Going back to the interaction between globalization and governance in Africa, section 5.3 presents progress on the MDG and other governance indicators.

\section{1. Economic Growth and Foreign Trade}

\subsubsection{Cape Verde}

During the 1970s, the growth rate of GDP was positive $(0.18 \%)$ but below the ECOWAS average (1.18\%). In contrast, it averaged 6.85\% during the 1980s while ECOWAS reported a decline of $-0.64 \%$. The reversal of fortunes continued during the 1990 s, with a growth rate above the ECOWAS average (3.89\% vs. $-0.20 \%)$ and over the $2000-6$ period $(1.04 \%$ vs. $0.86 \%)$. Although the causal study of growth is beyond the scope of our research, Cape Verde's improved growth performance follows the policy and institutional reforms described above. Describing their impact on exports, these were derived mainly from a relatively limited natural resource base. During 1988-1997, exports consisted mainly of primary sector products, namely fish and crustacean, and so were neither diversified nor high value-added. The 1976 decision to join ECOWAS was possibly one of the few exceptions to the otherwise protectionist trade policy. In practice, ECOWAS trade is of reduced importance, as ECOWAS members produce similar manufactured products. Clearly of greater importance was the decision to diversify production during 1992-6, which went hand in hand with greater trade openness and a market-orientated policy stance. As a result, exports grew substantially. After a 
dramatic decline of over 40\% in 1993, exports surged to almost 4\% in 1997 (IMF, 1998). The destination of exports also changed, as these were now directed mainly towards the European Union, particularly Portugal and Spain. Most of the export growth, however, has been in tourism notwithstanding the cyclical efforts to diversify the fishing and industrial sectors since the 1990s.

When the government shifted away from a policy of state-control to a free-market one in 1988, tourism also began to development substantially. In line with this policy change, Werlin (1996) observes that this sector's development entailed the synchronization of public and private investment in infrastructure. Legislation was also passed to encourage tourism, which included streamlining approval of qualified projects, allowing for a gaming industry and setting up a regulatory and enforcement framework. Furthermore, a standard service fee was levied on the users, as opposed to service providers, which helped finance tourism. Direct public investment in infra-structure construction, such as hotels and transportations, was also pursued. Tourism's contribution to GDP increased from approximately 2\% in 1995 to 5\% in 2000 and 10\% in 2005 (Mitchell, 2008). As noted in IMF (2008a), the balance of payments changed from being very dependent on international aid and emigrants' remittances to being based on tourism and tourism-related foreign direct investment. In 2001, services exports and foreign direct investment surpassed for the first time transfers as a percentage of GDP. Indeed, Cape Verde became the fastest growing market within the group of tourism based economies whose travel exports have exceeded 10\% of GDP for at least one year during 1998-2007, reporting an average annual growth rate of tourism services around 30\% during 2000-2006. During the same period Croatia registered an average annual growth rate of $20 \%$, the second highest. Tourism is highly pro-cyclical, however, so an excessive reliance on it increases output volatility unless exports of goods and services are sufficiently diversified. 
Unfortunately, tourism is absent from the OECD database used in our empirical work.

When it returned to power in 2001, PAICV pursued growth-orientated policies whilst rationalizing and reducing import taxes and seeking to rein in the budget deficit (IMF, 2005). It also promoted trade integration through increased access to preferential markets, such as the United States (African Growth and Opportunity Act - AGOA), European Union (Cotonou agreement). Joining the World Trade Organization in 2008 required a transparent and predictable trade and foreign investment environment, which accelerated Cape Verde's global integration. Although recently graduated to middle income the status, it still benefits from preferential market access for least developed countries. Recent governments have continued the reform process, including those of relevance to financial and exchange markets. Growth has been sustained by the service sector, namely transports, hotel and restaurants and communications, and also due to increased spending on education and improved governance. Indeed, the importance of the service sector, largely in tourism, was evident as early as 1980. Its continued success depends on further improving required infrastructure, namely good communications and a liberalized air transport market (Lourenço and Foy, 2003). Cape Verde's business cycles have thus become more synchronized with developed economies following increasing trade and financial integration into the world economy: Ribeiro, Martins and Loureiro (2008) make this an argument for "euroization" and the stability of a real effective exchange rate where the euro and dollar shares are equal to $1 / 2$ (Table 5.1) could be used in supporting such policy recommendation. On the other side, the labor market is relatively rigid and administered prices still exist e.g., in the energy sector. Thus structural problems persist and they make adjustment to external shocks more difficult. 
Regarding foreign financing sources, emigrant's remittances accounted for $12 \%$ of GDP in 2006, and their low volatility has allowed for consumption-smoothing in response to external shocks. However, remittances have become more pro-cyclical in recent years, e.g. the correlation between (de-trended) GDP and remittances was around 65\% for the period 19802006. This fact may be associated with investment-driven flows rather than traditional consumption-smoothing behavior. Since financial flows are far more volatile and less prone to act as a buffer in times of crisis, this is another challenge to Cape Verde: reforms are a necessary but not sufficient condition for success. Adequate implementation and control is also required to ensure that increased foreign direct investment translates into higher growth and employment.

Industrial policy in the 1980s was characterized by less state intervention and more privatization, which led to the creation of a vibrant private sector that contributed positively to growth. On this score, the literature shows a clear link between private ownership and economic growth. According to Plane (1997), privatizations are a means to reduce government loans, equity, subsidies, and explicit or implicit government guarantees for borrowing, which contributes towards competitiveness and a more efficient market economy.

In terms of competitiveness, the relative stability of Cape Verde’s real effective exchange rate since 1992 has already been mentioned. This is largely attributable to the Cape Verde Escudo’s peg, first to a basket of currencies during 1977-98 and to the Euro thereafter (Table 5.1). Exchange rate changes have thus not played a major role in engineering gains in competitiveness. Moreover, the low volatility reflects the control of inflation over the 1990's.

\subsubsection{Mozambique}


GDP data shows a similar, though slightly worse, comparative performance in the preindependence period, where the country grows at an average rate of $4.6 \%$, while SADC average was close to $5 \%$, then the period of social and political unrest, where we watch a general regional slowdown and a severe recession in Mozambique (an average rate of $-1.6 \%$ while SADC average growth rate equals 1.7\%), and finally, in the post-war period, Mozambique grows at a fast rate (averaging about $8.5 \%$ p.a.), while the region grows at a considerably slower rate of $3.4 \%$, less than half of Mozambique's. The civil war is characterized by both a regional slowdown and a significant decrease in Mozambique’s GDP per capita. While SADC still manages to growth at a rate of less than $1 \%$ p.a., Mozambique's GDP per capita falls on average 3\% per year. After the severe recession of the late 1970s and 1980s, when Mozambique fell back in comparison to its neighbors, Mozambique more than doubles its GDP per capita and starts to close the gap relative to the SADC average.

Export specialization has gone hand in hand with GDP growth, possibly due to the megaproject related exports, which increased appreciably since 2000. Products such as aluminum and electrical energy now dominate exports, while prawns or cashew lost significance. The average trade share of world exports more than doubled in the 2001-2006 period relative to 1991-00 but remains lower than in comparator groups in Africa and Asia ${ }^{30}$. While most Mozambican exports are directed to OECD countries, SADC is also a preferred destination, making up over $20 \%$ of the 2007 total, of which 16 is accounted for by South Africa. This increase is due almost exclusively to mega project-related exports, rather than a diversified performance associated with extensive competitiveness gain. Mozambique’s revealed comparative advantages are in the production of aluminum, gas, electrical energy and wood

\footnotetext{
30 Lledó et al. (2007) compare Mozambique with Sub-Saharan Africa (SSA) and Indonesia, Malaysia, Philippines and Thailand (ASEAN4) instead of SADC average. It rose from 0.01 to 0.02, whereas SSA rose for 1.5 to 1.6 and ASEAN4 remained constant. Since the early 1990s, exports have expanded at an average rate of $10 \%$ per year. According to 2007 WTO Trade Policy Review, exports reached over \$2.4 billion.
} 
articles, reflected in terms of trade which improved significantly more than in comparator groups in Africa and Asia. As aluminum prices rose, the terms of trade improved by $7 \%$ in 2001-06 as opposed to $0.5 \%$ during 1991-2000. These industrial exports are directed mainly to developed countries, whose share in the share in total exports toward those countries from 40.1\% in 1991-01 to 63.9\% in 2002-05 (Lledó et al, 2007, p. 61). Considering traditional exports, Mozambique’s main agricultural exports are cashew nuts, sugar cane, cotton fiber and timber. Other products include sisal, tobacco and fruits such as banana, citrus and mango. The main fisheries product, prawns (shrimp), continues to be among the country's top exports (and the largest agricultural export in 2007). Unlike the typical cases of export specialization, in Mozambique, these grew by an annual average rate of $4 \%$ whereas the growth of mega project-related exports was over 10\% yearly, on average (additional evidence in Easterly and Resheff, 2010).

In terms of competitiveness, Mozambique’s real effective exchange rate (shown in Table 5.1, with euro and dollar shares equal to $1 / 2$ ) has tracked the SADC average since the mid-1990s whereas before it was clearly less competitive than the sub-region. Nevertheless, both Mozambique and SADC are less competitive than South Africa, especially in recent years. Based on our reading of the 2006 and 2007 World Bank Enterprises Surveys in section 5.3, trade liberalization has yet to yield substantial improvements in firm-level competitiveness. While Mozambique has better infrastructures (particularly on water, electricity and internet), less corruption and a generally better regulatory environment than SADC, PALOP and SubSaharan Africa, it has less developed financial markets, a state where rule of law grounded, less export-oriented firms and less technology licensed to foreigners than the benchmarks (additional evidence in La Porta and Schleifer, 2010). 
Notwithstanding the progress achieved thus far, Mozambique also faces a number of challenges. As it depends on foreign aid, revenue and administration reform as well as a stronger fiscal regime towards mineral and oil resources will be required for the government to enforce an "exit strategy" which enables it to raise revenue for its own, to finance at least current expenditure as soon as the MDGs are achieved (Lledó et al., 2007). While it is true that Mozambique has a strong export record when one considers its share of world exports over the last few years, this achievement has been primarily due to specific mega-projects, most noticeably in the aluminum sector. Moreover, its trade pattern is sometimes the result of protectionist policies, such as tax exemptions and qualification as export-processing zones that allow companies to import goods duty free and benefit from tax incentives. Two examples are the sugar and cashew industries. In the late 1990's, an import tax on sugar led to increased domestic sugar production and an export tax on raw cashew nuts penalized small exporters while encouraging small and medium-sized cashew processing. In this case, the pattern of specialization is clearly linked not only to comparative advantage but also to trade policy.

That said, Mozambique’s trade regime is not too restrictive. In 2006, the average tariff was in line with the rest of SADC, there were no significant non-tariff barriers according to the IMF and the process of tariff disarmament will likely continue. As a result, the maximum tariff has declined from 35\% in 1999 to 20\% in 2006. Mozambique’s business environment is still relatively weak. The Ease of Doing Business indicators for 2006 suggest that custom procedures, business registration and contract enforcement still perform poorly against other SADC members. Mozambique was one of the countries that benefited most from the initiatives for Heavily Indebted Poor Countries and Multilateral Debt Relief (IMF, 2008b). Coupled with a cautious macroeconomic stance, debt relief has allowed for increased spending, especially in the health and education sectors. However, long-term fiscal 
sustainability hinges crucially on the widening of the tax base and on economic growth underpinned by high-quality structural investments.

\subsection{Macroeconomic Policy and Financial Reputation}

\subsubsection{Exchange Market Pressure}

The empirical results in section 4 did not use EMP and real effective exchange rate indices due to database incompatibilities but they did establish that lower budget deficits (less than $7 \%$ of GDP) are associated with convergence for both ECOWAS and SADC. Not unrelated, Cape Verde and Mozambique also compare favorably to respective sub-regional averages in financial reputation. As discussed in Macedo et al. (2009), this can be proxied by EMP, a weighted sum of the nominal depreciation rate, changes in foreign reserves (excluding gold) and changes in the interest rate differential (from International Financial Statistics and central banks’ websites), i.e.

$$
E M P_{t}=\Delta e_{t}+\eta_{r} \Delta r_{t}+\eta_{i} \Delta\left(i_{t}-i_{t}^{*}\right)
$$

The weights for reserves and for the interest rate differential are given by the standard deviation of depreciation relative to the respective variable, to avoid that the most volatile components of EMP dominates the others. As mentioned, according to the governance indicators reported in Table 3.7, Cape Verde compares well to the ECOWAS average. Lopes and Santos (2010) note, however, that this institutional portrait misses the "financial credibility factor” which they analyze through EMP using monthly data from 1990 to 2005, both in a descriptive sense and in a model-dependent framework. Mozambique’s mixed record compared to the SADC average is shown in Table 3.7. Yet it behaves well in terms of political stability and voice and accountability ${ }^{31}$. 
Lopes and Santos (2010) distinguish between fixers and floaters as follows. The seven Franc CFA countries (Benin, Burkina Faso, Côte d’Ivoire, Mali, Niger, Senegal, Togo) and GuineaBissau peg to the euro in ECOWAS while Seychelles and Zimbabwe peg to the dollar in SADC $^{32}$. Ghana, Nigeria, Sierra Leone, Gambia are floaters in ECOWAS and Zambia, Tanzania, Mauritius, Malawi, Madagascar and South Africa are floaters in SADC. They also find that real exchange rate depreciation improves financial reputation in Cape Verde while doing the opposite in Benin, where it increases EMP mean and volatility.

If financial reputation is defined as low EMP with low volatility, then fixers behave better than floaters both in ECOWAS and SADC. Conditional volatility and mean EMP, reported in Figures 5.1a, b and 5.2a, b for ECOWAS (without Nigeria) and SADC (without South Africa), strengthen conclusions from the unconditional volatility and mean EMP. Comparing Mozambique's EMP performance to SADC except South Africa (which dominates the weighted average), Botswana, Lesotho, Namibia, Swaziland because they are pegged to the rand, and Zimbabwe because of the huge devaluations in 1998 and 2000, the standard deviation of Mozambique's EMP has converged to that of Seychelles. The fixers, taken as a whole, behave very similarly to South Africa, given that Lesotho and Namibia are pegged to the rand and Botswana is pegged to a basket of currencies where the South African rand has an overwhelming weight. From 1994 to 2008, Mozambique’s EMP mean has behaved similarly to the one of South Africa but, from 1999 on, its volatility has converged more sharply towards the one of Seychelles. Mozambique also has a few EMP “crises” (taken to be extreme values of EMP), none of which severe, behaving better on this account than several economies

\footnotetext{
${ }^{31}$ Figure 1 in Lopes and Santos (2010) shows the tremendous improvements in Mozambique as soon the war is over, compared to SADC and Great Britain. Again it misses the "financial credibility" factor.

32 Botswana, Lesotho, Namibia and Swaziland peg to the rand so they float relative to the dollar. Lopes and Santos (2010) acknowledge that this makes them effectively neither fixers nor floaters but a third category.
} 
in the region, such as Tanzania, Mauritius and Malawi. In SADC, the gap between fixers and floaters is not as wide as in ECOWAS.

For the impact of domestic credit in EMP variance, Mozambique appears with a positive relationship that indicates the opposite of Cape Verde. It seems that these countries did not avoid the volatility and uncertainty on EMP with monetary expansions through domestic credit. But if we complement this result with the one obtained for the coefficient of domestic credit variation in the mean equation for Mozambique, then volatility is not as harmful given that Mozambique was able to reduce its mean EMP when credit was expanded, although they did not behaved so well in controlling the volatility. In Mozambique, moreover, the initial real depreciation is followed by nominal depreciations, which increase EMP and incite speculation.

In the SADC floaters group, Mauritius and South Africa display the most credible results on our key indicators, as well as other coefficients. However, Mozambique has also some positive conclusions, as the risk-return relationship or the domestic credit effect on the EMP mean. Cape Verde has had a remarkable degree of credibility and sophistication of its exchange markets, undoubtedly due to the quality of the institutional framework. Due to its natural focus on political freedom and accountability, the governance indicators presented in Table 3.7 and below overlook the effect of financial expectations. Mozambique, too, despite lagging behind Cape Verde, has also some good results, very much in line with other floaters in the region, and better in some accounts (namely, the absence of any severe crises, a conditional volatility close to a fixer's and a risk-return effect pointing the right way unlike many other countries in the region). While Mozambique’s financial reputation is weaker than Cape Verde’s, it seems to be heading the right way. We now described the foreign exchange market in greater detail for each one of the two countries. 


\subsubsection{Cape Verde}

On this score, Cape Verde's track record improved substantially given that, following independence, high budget deficits were the order of the day. The reason for expansionary fiscal policy was the relatively large expenditures required to improve living conditions, run the state-controlled industrial sector and pay for the high level of imports. The deficit was also high due to interest payments on domestic and foreign debt, leading to a loss of foreign exchange reserves and financial reputation. It was only in the late 1990s that the deficit was reduced. This change was accompanied by measures to control inflation and strengthen the financial sector. In 1997, a program was adopted that did away with domestic bank financing to be substituted by that obtained from foreign sources. As a result, the 1998 budget deficit was financed entirely by foreign creditors whereas domestic creditors had accounted for $10 \%$ of GDP and foreign one almost 1\% in 1997. The peg to the Euro, which allowed for low inflation rates and increased financial reputation, was crucial in obtaining the needed international finance. The government also speeded up the privatization process, improved tax collection and increased the recovery of debt obligations from public enterprises. Current primary expenditure was curtailed to offset higher interest revenue and the government abstained from pre-financing donor-supported investment projects. The composition of the expenditures was also modified while maintaining their level. With these measures, the budgetary position changed from a deficit $15.1 \%$ of GDP in 1997 to a surplus of $0.5 \%$ in 2000 .

The 2001 elections brought about some fiscal slippage but the newly elected PAICV government then sought to reduce the deficit, as well as domestic and external public debt, without overly increasing the tax burden. More recent reforms have streamlined and rationalized taxes on imports, accompanied by a general reduction of customs duties and 
excises. At the same time, public spending was redirected towards education, health, and other priority areas, in accordance with the government's poverty reduction strategy. Transfers and subsidies were also reduced substantially, notably subsidies to large public enterprises. As a consequence, current revenues increased from approximately 21\% of GDP in 2001 to 23\% of GDP in 2004, while current public expenditures were kept constant at around $21 \%-22 \%$ of GDP during the same period. The adoption of an IMF mid-term program in 2006, supported by a new non-financial instrument - Policy Support Instrument (PSI) - confirmed Cape Verde's commitment to maintain the pace of reforms and close dialogue on macro-economic policy. The program, which will be completed in 2010, will assist Cape Verde in reducing fiscal risks and minimize the impact of external shocks on its economy by promoting the necessary structural reforms under IMF advice and supervision. While AEO (2010) maintains a positive assessment on financing, the threats to the EU financial system are bound to have a negative effect going forward.

In 1976, Banco de Cabo Verde started operations, succeeding to Banco Nacional Ultramarino (the former issuing bank) and Banco de Fomento Nacional (a state-owned development bank). The currency was pegged to the Escudo but in 1977, following Portugal's devaluation, the peg shifted to a basket of currencies. During the eighties, several reforms were put in place, namely through the use of information and communication technologies in the central administration and a network of bank offices spreading through the archipelago: A newly created investment department managed programs supporting productive activities. From 1988 on, a vast program of reforms began promoting trade liberalization and privatizations while the government remained responsible for infrastructures. Successive governments continued these reforms, accompanied by an increasing concern with the role of education and good 
governance. High growth in transports, hotels, restaurants and communications was associated with these reforms making Cape Verde largely dependent on services by 1980 .

In 1990, monetary and exchange rate policies as well as the supervisory and lender of last resort roles of the central bank were reinforced by new by-rules but commercial and development activities continued until September 1993. Starting April 1st, 1998, the Cape Verde Escudo was pegged to the Euro in the framework of an agreement with Portugal Ribeiro, Loureiro and Martins (2008) describe the agreement while Macedo and Pereira (2006) associate it with a substantial reduction in EMP and lower inflation, as described above. In 2002, deficit financing by the central banking was also formally prohibited. In practice, the government has not needed to rely on this type of financing due to the receipt of donor-aid and the sale of treasury bonds with medium-term maturities. Fiscal policy has also been prudent with a medium-term fiscal strategy for 2008-2010 approved by the IMF. Fiscal reforms were accompanied by an increase in tax effort, particularly of income tax, as corporate tax rates are still relatively low. Together, this environment of fiscal responsibility has allowed Debt Sustainability Analysis to classify Cape Verde’s debt risk as low. The external position continues to depend on transfers, mostly migrants remittances. The decreasing role of transfers and the increasing role of portfolio and direct investment from abroad erodes remittances' role as a buffer for households. It is likely that second and third generation emigrants will be less inclined to send remittances and will only invest in Cape Verde when it is profitable to do so. The government will have to take cognizance of this fact when designing and implementing its medium-term development strategy.

\subsubsection{Mozambique}

Mozambique's economic recovery in recent years has clearly entailed a more effective and prudent fiscal policy. After the 1992 peace-accord, there was a significant reduction of current 
expenditures (from 20\% in 1992 to $10 \%$ three years later). In fact, except during 2000-02, revenues have exceeded current expenditure since 1995, while investment expenditure (mainly on mega project-related investments) has been paid with grants. Such a strategy, in combination with a sound monetary policy (particularly since 1996-97) and significant trade liberalization (as discussed above), has allowed for higher growth rates, private investment and lower inflation. We also observe a shift in the utilization of public resources, with new emphasis being given to sectors such as health, education and agriculture, along a povertyreduction strategy undertaken principally since $1998^{33}$. At present, it seems that budget equilibrium is not a goal for the Mozambican policymakers. Moreover, the tax effort is still very low, although it has increased recently. As such, it is important for government to increase taxes on big projects and to create procedures that increase compliance in order to widen the future tax base.

Mozambique’s currency, the Metical, was created in June, the 16th, 1980 by Law 2/80 and the colonial administration's banknotes ceased to circulate. The first credit conceded by the International Development Association, though, was only granted in 1985; the second was in 1987 and successive agreements were signed in the following years. Mozambique has benefited widely of the support of the IDA, either financially, or through its technical expertise. The main accomplishments, as reported in IDA (2007), involve the liberalization of trade, financial sector reform (with a separation between the commercial and central banking, with competition in commercial banking, improved health conditions, good investment climate and privatizations in several sectors. On January, 31st, 1987, the Metical was pegged to the US dollar instead of being pegged to a basket of six currencies reflecting shares in

\footnotetext{
${ }^{33}$ For instance, according to official budget figures, from 1998 to 2000, health and education accounted for 26$28 \%$ of central governmental spending.
} 
goods and services transactions but authorities reverted to a basket of ten currencies in April 1988.

In the late eighties/early nineties, policymakers started aiming at transforming Mozambique in a market economy. Throughout 1989, several capital account liberalization measures were pursued: agencies of the Bank were allowed to conduct foreign operations (April) and private financial firms were given more freedom to conduct foreign exchange operations (July). On November, 30, finally, the new Constitution declared that Mozambique would aim at being a market economy.

In May 1993, interest rates were semi-liberalized and left to the free market, with the Central Bank determining maximum and minimum bounds. On June, exchange rates from the Secondary and Official Exchange Markets were unified. By 1994, the interest rates were completely liberalized. Through the following years, several liberalizing measures were undertaken and the legal foundations of the exchange market were perfected.

In June 1999, in a move that was very important for Mozambique’s development, external debt in the amount of $\$ 3.7$ billion is erased by the Heavily Indebted Poor Countries Initiative of the IMF. In 2000, a reinforced initiative was put in place to the favor of Mozambique. In 2003, further measures were taken to ease capital operations by non-residents in the Stock Exchange. In fact, AEO (2008) claims that debt relief in the early 2000s was a condition for most of the development Mozambique is experiencing today. In 2005, Banco de Moçambique started intervening in the Interbank Foreign Exchange Market through weekly auctions of foreign exchange and a Multilateral Debt Relief Initiative was launched. 
Mozambique's inflation rate has been under control for some time now and it now ranks amongst the lowest in the SADC. Indeed, the control of inflation control has been the main objective of monetary policy since 1987, upon the approval of an economic recuperation plan, and even more so since the early 1990s. The data shows that Mozambique managed to control inflation since 1991, averaging consistently below its SADC counterparts, and particularly Angola. The inflation rate has been about half of the average in SADC since the nineties. This accomplishment is significant if we consider that in this period Mozambique experienced a transition from a central-planned, public-owned economy to a free-market economy, which is known to create an upward pressure on inflation ${ }^{34}$. More recently, Banco de Moçambique has also adopted several important measures, namely daily liquidity forecasting and sterilization of changes in the monetary base, which improved the conduct of monetary policy.

This relative stability in inflation has been accompanied from the 1990's onward by a steady depreciation of the Mozambican Metical's exchange rate against the U.S. dollar, which is in line with other depreciation rates of SADC currencies. Regarding its external position, Mozambique has experienced trade deficits and negative factor incomes balances, which have been partially compensated by transfers (with the exception of 2006, where transfers were in excess of the shortfalls). The trade balance improved up till 2006 due to high aluminum prices and export growth of cashew nuts, sugar, prawns and tobacco. However, the increase in the oil price and a decrease in traditional exports in 2007 deteriorated the trade balance. Indeed, financing a current account deficit which reached 22\% of GDP in 1999 required debt relief.

\subsection{Millennium Development Goals and Governance Indicators}

\footnotetext{
${ }^{34}$ See Andersson and Sjöö (2002) for the structural adjustment’s impact on inflation.
} 
The information on MDG is drawn from a report prepared at the request of the Guinean presidency of CPLP (IICT, 2007) and from AEO: the \%age of satisfactory outcomes in PALOP is $31 \%$ according to the first source but $26 \%$ according to the second, as shown in Table 5.2. The corresponding percentage for the whole AEO sample of 53 countries is $31 \%$ in 2007 and 41\% in 2009 and 2010. Fewer entries with missing data appear in AEO (2009, 2010) than in previous issues, at least for PALOP, and the criteria used seem to have stabilized together with the percentage. The ranking found in the first source remains that found in Tables 3.3 through 3.5, Cape Verde followed closely by Sao Tome and Mozambique only marginally above Guinea Bissau and Angola, whereas the Sao Tome and Mozambique have the same average AEO score. Table 5.3 provides more detail on the quantified MDG presented in Table 5.2 and compares Cape Verde and Mozambique to the ECOWAS and SADC average as before.

(Insert Tables 5.2 and 5.3 here)

On the eradication of poverty, Cape Verde has one of the lowest shares of the poorest quintile in national consumption. Using the data available, we see that it is slightly worse than the average ECOWAS member. Angel-Urdinola and Wodon (2007) argue that relative poverty increased between the 1988/89 and 2001 surveys, based on the increase in the Gini coefficient from 50.2\% to 53.83\%), while absolute poverty measures decreased dramatically. Mozambique, meanwhile, has a slightly larger share (5.4\%) of consumption of poor people when compared to the SADC average. Although the US has a comparable figure, its definition of poverty is a relative and not an absolute one. In view of Mozambique’s recent evolution IMF (2008) considered it likely that this goal will be attained by 2015 and the 2009 and 2010 AEO \%ages of satisfactory performance are uniformly better than in 2007. In fact they are higher in 2010 than in 2009 so that they do not yet show any effect of the crisis - except for 
objectives 5 and 7, maternal mortality and access to water, which fall to one half of the previous value.

On MDG 2, net enrolment in primary education, Cape Verde has actually decreased slightly. However, the enrolment level is very high even by the developed world's standards. Notably, Cape Verde is well ahead its ECOWAS partners, which reflects its focus on education and the quality thereof. For Mozambique, the net enrolment in primary education has increased significantly since the 1990’s, especially during 2000-06. Indeed, Mozambique has improved remarkably when compared to most SADC countries but stills lags behind them. The same can be said for its level of literacy. On MDG 3, gender parity, Cape Verde is better placed than its ECOWAS partners but some of them are now catching-up fast. Gender parity in Mozambique is one of the poorest in SADC but, at the same time, it registers a sustained and strong improvement. With respect to child mortality, MDG 4, Cape Verde's is by far the lowest in ECOWAS but still far short of the level in developed countries. Even so, it has decreased significantly. On this score, Mozambique is improving rapidly, as its child mortality rate has decreased to 153.67 per thousand, which is much better than the SADC average. IMF (2008) foresees that this MDG will probably be reached by 2015. For maternal health, MDG 5 (for which there is only one observation, and a higher percentage of satisfactory performance was reached in 2009 than in 2010), Cape Verde is the best in ECOWAS. Mozambique’s maternal mortality rate was below the SADC average in 2005, which is in line with the improvement in child mortality and in public health as a whole. MDG 6, the incidence, prevalence and death rates associated with tuberculosis, show much lower figures in Cape Verde than for ECOWAS. There is no data on HIV prevalence in Cape Verde as far as we are aware. The prevalence and death rate of tuberculosis grew more in Mozambique than in SADC members while HIV/AIDS statistics show a worrying increase in infection rates among young people. 
The goal of sustainable development is often proxied by the proportion of the population having access to safe drinking water source. It is much higher in Cape Verde than in ECOWAS. Similarly, the proportion of the urban population is also higher in Cape Verde but a significant catching-up is noticeable in ECOWAS member states. In Mozambique, the proportion of population having access to improved sanitation facilities has increased from 22\% to 31 \% between 1995 and 2006: it lags behind other SADC partners but is quickly narrowing the gap. The same can be said of the proportion of the population living in slums, which has fallen drastically since 2001 (whereas in the SADC partners the reduction has been modest). The weak spot of this MDG lies in the water quality since the improvement in the proportion of population having access to an improved drinking water source has been negligible while the proportion of the urban population has actually decreased from $83 \%$ to 71\% when comparing 1995 to 2006. This is again a case where the \%age of satisfactory performance reached in 2009 was about double that reported in 2010, under 30\% as opposed to slightly over $60 \%$.

The global partnership for development is often illustrated by debt service as a \%age of exports of goods and services, as done in Table 5.3. This has been historically lower in Cape Verde when compared to ECOWAS and has decreased over time, but ECOWAS decreased more markedly when looking at the year-by-year numbers. Mozambique’s debt service has fallen markedly and the period of high growth coincides with that of the donor community's relief of debt, as discussed in the previous sub-section.

(Insert Tables 5.4 here) 
Coming back to the comparison of governance and freedom indicators appearing in Tables 3.4, 3.5 and 3.7 above, Cape Verde’s Economic Freedom Index has improved since 1996, when it obtained 49.7 points. However, trade freedom (45), government spending (30.9), financial freedom (10) and freedom from corruption (30) were below average. The lack of financial freedom was due to commercial banks’ weak independence excessive government spending due to weak industrial policies in the transition to independences. Financial freedom only ranked higher in 2002 (50 points), when a law that gave more independence to the central bank was approved. As for government spending, this category reached similar values to current ones in 2004 (around 70 points) because political measures aimed at controlling the budget deficit started to be effective. In the years following 1996, the country's score has been improving when compared on a year-to-year basis, except during 1997, 2003, 2005 and 2007. In 2010, Cape Verde reached its maximum score (61.8) and is classified as the $78^{\text {th }}$ freest economy in the world. Above average items include business freedom (63.3), trade freedom (65.5), fiscal freedom (65.6), government spending (65.3), monetary freedom (74.5) and property rights (65). Freedoms in need of improvement were investment freedom (69), financial freedom (60), freedom from corruption (51) and labor freedom (48.1). In comparative terms, Cape Verde ranked 7th out of 46 countries in Sub-Saharan Africa, with a regional score much higher than the average ${ }^{35}$. Luiz et al (2010) present a set of institutional indicators for Mozambique for the period 1900 through to 2005, reproduced in Figure 3.3 above. The first tracks political freedoms and is unique in its duration and complexity even though it correlates highly with the Freedom House combined index of political and civil liberties. The second index constructs a property rights measure which has not existed previously but also reveals a fairly strong correlation with the other index. They explain this as

\footnotetext{
35 This happens not only thanks to relatively good performances in the above-mentioned categories but also due to the fact that its regional partners perform even worse in those categories where Cape Verde performs poorly. For example, Cape Verde ranks 47th out of 179 countries in Transparency International's 2008 Corruption
} 
follows: "The Portuguese government during several phases of its colonial administration went to great lengths to develop a more formal system of property rights even whilst politically suppressing the participation of the vast majority of its population and this drives down the correlation between these two indices to 0.46 under colonialism. If we focus on the post 1975 period the correlation shoots up to 0.93 which indicates that a deterioration in political freedom from independence onwards is associated with a lack of economic freedom and security, whilst an improvement sees a rise in economic freedoms as well”.

IICT (2007) includes the following six governance indicators from the World Bank Institute: freedom and accountability (FREE), stability and absence of violence (STAB), government efficiency (EF GV), quality of regulation (Q REG), quality of justice (JUST) and control of corruption (CORR) which were reported in Table 3.7 above. Good governance has been one of the main features of Cape Verde's development. Rule of law and accountability stem from the fact that democracy is well established and that free elections take place regularly with the results not being disputed. The only aspect that fares worse is regulatory quality but this indicator still fares better than most ECOWAS member states. Education is a major concern for Cape Verde governments: between 1970 and 1990, the number of children leaving school with secondary education increased dramatically. In 1990, half of the children in rural areas attended secondary school and $60 \%$ of girls received secondary education in urban areas (see Goujon and Wils, 1996). The literacy rate in the people between 15 and 24 years old is the highest in all ECOWAS. With respect to Mozambique, no significant evolution is noticeable between 1996 and 2006 for most indicators, and then it improves gradually. The exception is the indicator of political stability and the absence of violence/terrorism, which has improved markedly.

Perceptions Index regarding the "freedom from corruption" indicator. However, Cape Verde ranks third when looking at only Africa countries, coming in after South Africa (first) and Botswana. 
The 28 indicators in the 2006 and 2007 World Bank Enterprise Surveys for which both Cape Verde and Mozambique report at least 10 answers are in Tables 5.4, panels 1 through 5. The indicators for regional groupings and Sub-Saharan Africa are simple averages of the countries, some of which are missing (2 out of 15 from ECOWAS and SADC, 12 in Sub-Saharan Africa). Relative to the average of their comparator countries (in parentheses), then Cape Verde has more developed financial markets, greater macroeconomic stability, less corruption and a state where rule of law is more grounded than ECOWAS, PALOP, Sub-Saharan Africa but less export-oriented firms, less technology licensed to foreigners, higher taxes and a heavier regulatory framework than the benchmarks. Mozambique has better infrastructures (water, electricity and internet) and less corruption than SADC, PALOP, Sub-Saharan Africa but less developed financial markets, a state where rule of law is less grounded, less exportoriented firms and less technology licensed to foreigners than the benchmarks.

(Insert Table 5.4 here)

\section{Conclusions}

The expansion, diversification and deepening of trade and financial links between countries over several decades presented an unparalleled opportunity to raise living standards and achieve the MDG. Development success under globalization, meanwhile, is less a question of relative resource endowments or geographical location than in past waves of globalization. Moreover, adequate development responses to globalization become all the more important as globalization increasingly affects political and economic governance, mainly by reducing national policy space and increasing institutional and economic interdependence at various levels. Under these conditions, interactions between globalization and governance can be either positive or negative, depending on the orientation and predictability of economic policies and the accompanying institutional arrangements but also on linkages between 
cultural, institutional and economic factors.

Against this background, we want to determine whether the interaction between globalization and governance is positive or not in Cape Verde and Mozambique so as to assess the extent to which they represent development successes in West and Southern Africa. Specifically, we attempt to identify lessons for successful governance based on meaningful national and regional comparisons of Cape Verde and Mozambique's development experience. Economic success under globalization for these countries entails, necessarily but not exclusively, positive market perceptions regarding outcomes such as trade diversification and narrowing of the income gap relative to the frontier. This aspect of success has to be, in turn, sustained by good governance and level of political and economic freedom that their citizens and residents enjoy. As such, policy and institutional reforms provide the context against which to interpret governance indicators and progress towards the MDG.

To identify macro-level policy and institutional combinations underpinning successful export diversification and economic convergence in ECOWAS and SADC, the empirical analysis establishes context-based objective metrics that assess the relative performance of Cape Verde and Mozambique in conjunction with evidence of a case-study nature. Given the severe lack of data over the period 1960-2004, this indirect approach to study trade-related development success in these two countries is unavoidable. We apply Three-Stage Least Squares and other estimation techniques, with broadly consistent results, to two main variables: the distance of a country's GDP per capita compared to that of the United States in order to capture economic convergence (ygap) and the inverse of the Herfindahl Index (neq5) as a measure of export diversification. Together with additional control variables, these two variables are a meaningful characterization of each country's diversification-convergence, which will be 
affected by the interaction between policy and institutional variables.

We first identify the determinants of diversification and convergence at the regional level. Then, we re-estimate the model for sub-samples that capture two different diversificationconvergence scenarios in each sub-region. The first sub-sample, denoted as the HIGH-regime, comprises countries that simultaneously exhibit high diversification and high convergence $\{$ ygap $<0.945 \&$ neq $5>4.5\}$ while the second, the LOW-regime, comprises those that exhibit the opposite combination $\{y g a p>=0.945 \&$ neq $5<=4.5\}$. This strategy allows us to highlight differences and commonalities in performance across regimes and regions including regional benchmarks, viz. Senegal for ECOWAS and Mauritius and South Africa for SADC.

The principal differences are that ECOWAS HIGH-regime countries are becoming more diversified whilst those of SADC are becoming less diversified. Opening up to trade is also an important driver of both convergence and diversification for the former, especially in the range of $45-75 \%$ of GDP, but not for the latter. In SADC HIGH-regime countries, economic and political freedom drive convergence, suggesting effective institutional arrangements. As for the commonalities or lessons present in the HIGH-regimes, we find that: 1) the expected twoway relationship always exists; 2) convergence always entails macroeconomic stability (inflation $<9 \%$, budget deficits $<7 \%$ of GDP); 3) political and economic freedoms are always greater, on average, when compared to the other cases; 4) freedoms always affect diversification policy as do government deficits, albeit in different directions across both subregions. However, increasing deficits always counteract prevailing diversification stance in both sub-regions, which we take to be a sign of regime credibility. The comparison across subregions, meanwhile, serves to highlight the importance of institutions irrespective of the sample chosen: economic freedom always affects diversification in ECOWAS while both 
freedoms affect it in SADC, where they affect convergence too. Efforts at monitoring the MDGs complement the context for export diversification across Sub-Saharan Africa (Cabral and Veiga, 2010) and for financial reputation in PALOP, ECOWAS and SADC (Lopes and Santos, 2010).

The estimated impact that Cape Verde and Mozambique have on their respective sub-regions, which accords with the intuition and implications of the posited two-way relationship, confirms the narrative of their long-term development. Based on our reading of this narrative, we identify the following common drivers of macro-level policy and institutional combinations as being associated the (different) two-way relationship of both countries: moving towards a market economy; opening up to regional and global trade; increasing economic and political freedom; pursing macroeconomic stability and financial reputation; ensuring policy continuity (especially in trade and industrial sectors) and focusing on human development (especially poverty reduction and education). These two case studies of positive G\&G interaction reflect on the potential for cooperative governance and peer-review mechanisms outside of its usual domain among OECD and EU member countries. For Cape Verde, in particular, the effects of the "culture of peace” should be stressed again, as it helped sustain the move towards a market economy, through greater trade integration especially with the EU and the US, culminating in the membership in the World Trade Organization. Multiparty democracy and greater political freedom and civil liberties allowed policy continuity across the political divide and improved human development. This is not to say that human development is sustainable in the face of the current global crisis. In effect, macroeconomic stability was threatened from outside but also through an insufficient attention to public and external deficits. If not appropriately monitored, this could threaten the positive interaction attained between globalization and governance. 


\section{References}

AEO (African Economic Outlook), Paris: African Development Bank and OECD Development Centre, various issues.

Amaral, Luciano (2009), “Old but New Questions back to the passage from Ancien regime to Liberalism”, in Macedo et al. (2009a).

Andersson and Sjöö (2002), “O sucesso Moçambicano no controle da inflação durante a transição para uma economia de mercado (1991-1996)”, Gabinete de Estudos do Ministério do Plano e das Finanças Moçambique.

Andrade, Mário D., Ed. (1978), Obras escolhidas de Amilcar Cabral, A Arma da Teoria, Unidade e Luta I, Lisboa: Seara Nova.

Angel-Urdinola, Diego and Quentin Wodon (2007), “Assessing Absolute and Relative Poverty Trends with Limited Data in Cape Verde.” Growth and Poverty Reduction: Case Studies from West Africa edited by Quentin Wodon, World Bank Working Paper No. 79, pp. 95-197.

Bastos, Paulo and Manuel Cabral (2007), “The Dynamics of International Trade Patterns”, Review of World Economics, volume 143, Number 2/July 2007.

Bliss, Christopher and Jorge Braga de Macedo (1990), editors, Unity with diversity in the European economy: the Community's southern frontier. Cambridge University Press, Cambridge.

Bonaglia, F., and K. Fukasaku (2003), 'Export Diversification in Low-Income Countries: An International Challenge after DOHA. OECD Development Centre Technical Papers 209. Paris: OECD. 
Bonaglia, Federico, Jorge Braga de Macedo and Maurizio Bussolo (2009), How globalisation improves governance, in Linda Yueh (editor), The Law and Economics of Globalisation, Edward Elgar, pp. 193-224.

Borges de Macedo, Jorge (1996), "Mares Abertos e Mares Fechados. Da Dialéctica do Confronto aos Problemas da Cooperação”, Actas dos $2 .{ }^{\circ}$ Cursos Internacionais de Verão de Cascais, Vol. 1, pp. 185-194, Cascais: Câmara Municipal de Cascais.

Bourguignon, Francois et al (2008), MDG at mid point, Brussels, September.

Branson, William, Jorge de Macedo and David Richardson (1987), Ford Foundation Proposal: Measurement and Estimation of Changes in International Competitiveness, NBER, May.

Cabral, Amilcar (1975), Análise de Alguns Tipos de Resistência, Lisboa: Seara Nova.

Cabral, Amilcar (1999), Nacionalismo e Cultura, Santiago de Compostela: Edicións Laiovento.

Cabral, Ana Maria (1995), Programa da Comemoração do XX Aniversário da Independência de Cabo Verde, Washington DC: Festival of American Folklore, Smithsonian Institution.

Cabral, S. I. A., (Ed.) (1987), Pour Cabral, Paris: Présence Africaine.

Cabral, Manuel Herédia Caldeira and Paula Veiga (2010), "Determinants of Export Diversification and Sophistication in Sub-Saharan Africa”, FEUNL Working Paper $\mathrm{n}^{\circ}$ 550, July.

Cadot O., C. Carrère and V. Strauss-Kahn (2007), Export diversification: what's behind the hump?. Centre for Economic Policy Research Discussion Paper No. 6590. 
Cardoso, Renato (1986), Cabo Verde : opção para uma política de paz, Praia : Instituto CaboVerdiano do Livro.

Causa, Orsetta and Daniel Cohen (2006), The ladder of competitiveness and how to climb it, Paris: OECD Development Centre.

Cleveland, W.S. (1979), "Robust Locally Weighted Regression and Smoothing Scatterplots". Journal of the American Statistical Association 74 (368), pp. 829-836.

Cleveland, W.S., Devlin, S.J. (1988). "Locally-Weighted Regression: An Approach to Regression Analysis by Local Fitting". Journal of the American Statistical Association 83 (403), pp. 596-610.

De Benedictis L., Gallegati M. and M. Tamberi (2006), Overall specialization and development: countries diversify!, The Review of World Economics (2009),145(1).

Easterly, William and Ariell Reschef (2010), African Export Successes: Surprises, Stylized Facts and Explanations, paper presented at the NBER research conference 2, Accra, Ghana, July

Eichengreen, B., Rose, A. K. and C. Wyplosz (1996), “Speculative Attacks on Pegged Exchange Rates: An Empirical Exploration with Special Reference to the European Monetary System”, in Canzoneri, M.B., Ethier W.J. and V. Grilli (eds.) The New Transatlantic Economy, Cambridge University Press, Cambridge.

Collier, P. and Gunning, J. W. (1999), "The IMF's Role in Structural Adjustment," Economic Journal, Royal Economic Society, vol. 109(459), pages F634-51, November.

Collier, P. (2007) The Bottom Billion: Why the poorest countries are failing and what can be done about it, Oxford University Press, Oxford. 
Eichengreen, Barry and David Leblang (2006), “Democracy and Globalization”, NBER Working Paper No. 12450, August and BIS Working Paper No 219, December.

Espírito Santo Research (2007), “Cape Verde Republic - Reality and Future”, February.

Fedderke, J. W. \& de Kadt, R. H. J. \& Luiz, J. M. (2001), "Indicators of political liberty, property rights and political instability in South Africa: 1935-97," International Review of Law and Economics, Elsevier, vol. 21(1), pages 103-134

Feyrery, James (2008), Trade and Income: Exploiting Time Series in Geography, Dartmouth College, December 2.

Flandreau, Marc and Frédéric Zummer (2004), The Making of Global Finance 1880-1913, Paris: OECD Development Centre Studies.

Frankel, Jeffrey (2010), Mauritius: African Success Story, paper presented at the NBER research conference 2, Accra, Ghana, July

Galtung, J. (1996), Peace by Peaceful means, peace and conflict, development and civilization, New Delhi: Sage.

Garoupa, Nuno and Jose Tavares (2009), “Institutions and Portuguese economic History: Implications and (Brief) Applications”, in Macedo et al (2009a).

Giovannini, Enrico, Joaquim Oliveira Martins and Michaela Gamba (2008), Statistics, Knowledge and Governance, presented at Committing Science to Global Development Workshop, IICT, 26 September (http://www.iict.pt/workshop/Papers/2008092903.pdf)

Gisselquist, Rachel and Robert Rotberg (2008), Index of African Governance, Harvard. 
Goujon, Anne and Annababette Wils (1996), “The Importance of Education in Future Population. Global Trends and Case Studies on Cape Verde, Sudan, and Tunisia”, IIASA Working Paper $n^{0} 138$, November.

Hausmann R., J. Hwang and D. Rodrik (2007), What you export matters. Journal of Economic Growth, 12(1), pp. 1-25.

Hausmann, R. and D. Rodrik. (2003), “Economic development as self-discovery.” Journal of Development Economics. 72, pp. 603-633.

Hausmann, R., and B. Klinger (2006), “Structural Transformation and Patterns of Comparative Advantage in the Product Space.” Working Paper No. 128 Center for International Development, Harvard University.

Hausmann, R., Hwang J. and D. Rodrik (2007), "What you export matters," Journal of Economic Growth, Springer, vol. 12(1), pp. 1-25, March.

Helpman E. and P. Krugman (1985), Market structure and foreign trade. The MIT Press, Cambridge (Mass).

Herzer, D., and F. Nowak-Lehmann D. (2006), "What Does Export Diversification Do for Growth? An Econometric Analysis.” Applied Economics 38, pp. 1825-38.

Hoeffler, A. E. (2002), “The Augmented Solow Model and the African Growth Debate.” Oxford Bulletin of Economics and Statistics 64(2), pp. 135-58.

Huang, Fali (2006), “The coevolution of Economic Development and Political Development”, mimeo Singapore Management University. 
Hummels, D., and P. J. Klenow (2005), “The Variety and Quality of a Nation’s Exports.” American Economic Review 95(3), pp. 704-23.

IDA (2007), “L'IDA en Action - Le Mozambique: du reddressement d'après-guerre à la relance de la croissance.”, Avril.

IICT (2007), “Relatório sobre CPLP e Objectivos de Desenvolvimento do Milénio”, a report for the Executive Secretary of CPLP by Jorge Braga de Macedo, Luís Brites Pereira, Joaquim Pina and João Jalles, Lisbon: Tropical Research Institute (IICT), October.

Imbs, J., and R. Wacziarg (2003), "Stages of Diversification.” American Economic Review 93(1), pp. 63-86.

IMF (1998), “Cape Verde: Statistical Tables”, Country Report No 98/31.

IMF (1999), “Cape Verde: Recent Economic Developments”, Staff Country Report No 99/58.

IMF (2008a), “Cape Verde Growth and Poverty Reduction Strategy Paper II (2008-11)”.

IMF (2008b), “Heavily Indebted Poor Countries (HIPC) Initiative and Multilateral Debt Relief Initiative (MDRI)—Status of Implementation”, September.

Kauffman, D., Kraay, A. and M. Mastruzzi, “Governance Matters VIII: Aggregate and Individual Governance Indicators, 1996-2008”, World Bank Policy Research Paper No. 4978

Kanbur, Ravi (2004), "The African Peer Review Mechanism (APRM): An Assessment of Concept and Design", Politikon, November.

Kohli (1986),“Democracy and development”. In J. P. Lewis \& V. Kallab (Eds.), “Development strategies reconsidered”. New Brunswick: Transaction Books. 
Koren M. and S. Tenreyro (2007), Volatility and Development. Quarterly Journal of Economics, 122(1), pp. 243-287.

Krugman P. and Venables A.J. (1990), Integration and the competitiveness of peripheral industry, in Bliss and Macedo (1990).

La Porta, Rafael and Andrei Schleifer (2010), The Unofficial Economy in Africa, paper presented at the NBER research conference 2, Accra, Ghana, July

Lledó, v., Peiris, S. and E. Kvintradze (2007), IMF, "Republic of Mozambique: Selected Issues”,IMF Country Report No. 07/258, July.

Lopes, Jose Mario and Fabio Santos (2010), “Comparing Exchange Market Pressure in West and Southern African countries”, FEUNL Working Paper $n^{\circ}$ 549, July.

Lourenço, Jaime and Foy, Colm (2003), “Cap Vert: Gouvernance et Développement.”, Centre de Développement de l’OCDE, Document de travail No. 225, Novembre.

Luiz, John (2009), Institutions and Economic Performance Implications for African Development, Journal of International Development, 21, 58'75

Luiz, John, Luis Brites Pereira and Guilherme Oliveira (2010), "Indicators of Political and Property Rights in Mozambique, 1900-2005, Wits Business School, University of Witwatersrand

Macedo, Jorge Braga de (1986), Collective Pegging to a Single Currency: The West African Monetary Union, in The Real Exchange Rate and Adjustment in Developing Countries, edited by Sebastian Edwards e Liaquat Ahamed, Chicago: The University of Chicago Press, pp. 333362. 
Macedo, Jorge Braga de (2001), “Globalization and Institutional Change: A Development Perspective”, in Globalization Ethical and Institutional Concerns, edited by Louis Sabourin and Edmond Malinvaud, The Pontifical Academy of Social Sciences, Acta 7, Vatican City, pp. 223-267.

Macedo, Jorge Braga de (2008), Regional integration and mutual knowledge: The case of the CPLP, presented at Committing Science to Global Development Workshop, IICT, 26 September (http://www.iict.pt/workshop/Papers/2008091401.pdf)

Macedo, Jorge Braga de (2009), Economic Advice and Regime Change in Portugal, in Francesco Franco (editor), Challenges Ahead for the Portuguese Economy, Lisbon: ICS, pp. 201-229.

Macedo, Jorge Braga de and Luís Brites Pereira (2006), The Credibility of Cabo Verde’s Currency Peg, Nova Economics Working Paper nº 494, September.

Macedo, Jorge Braga de and Luís Brites Pereira (2007), Diferencialidade Portuguesa na Globalização, Negócios Estrangeiros, 11(2), July, pp. 223-236.

Macedo, Jorge Braga de, Barry Eichengreen and Jaime Reis (1996), editors, Currency Convertibility: The Gold Standard and Beyond, London: Routledge.

Macedo, Jorge Braga de, Joaquim Oliveira Martins and Luís Brites Pereira (2007a), "How Freedoms interact with globalization”, presented at conference on globalization and democracy, Princeton University, September 27-28, revision in progress.

Macedo, Jorge Braga de, Luciano Amaral, Álvaro Ferreira da Silva and António Castro Henriques (2009a), editors Nove Ensaios na tradição de Jorge Borges de Macedo, Lisboa: Tribuna da História em colaboração do CG\&G e IICT. 
Macedo, Jorge Braga de, Luís Brites Pereira and Afonso Mendonça Reis (2009b), Comparing

Exchange Market Pressure across Five African Countries, Open Economies Review: Volume 20, Issue 5, p. 645.

Macedo, Jorge Braga de, Joaquim Oliveira Martins and Bruno Rocha (2009c), “Are complementary reforms a "luxury" in developing countries?”, Workshop FRDB/IZA "Tracking Structural Reforms" Milano,13 March.

Macedo, Jorge Braga de (2010), “Global crisis and national policy responses: together alone?”, March.

Maddison, Angus (2001), The world economy: a millennial perspective, Paris: OECD.

Maddison, Angus (2007), Contours of the World Economy 0-2030 AD, Oxford University Press.

Maravall (1995), “The myth of the authoritarian advantage”, in L. Diamond \& M. F. Plattner (Eds.), Economic reform and democracy, Baltimore: The Johns Hopkins University Press.

Maxwell, Kenneth (2004), Conflicts and Conspiracies Brazil and Portugal 1750-1808, New York: Routledge (originally published in 1973).

Mitchell (2008), “Tourism Development in Cape Verde: The policy challenge of coping with success”, Overseas Development Institute.

Nye, Joseph (2002), "A Whole New Ball Game" Financial Times Dec 28.

OECD (2003), Globalisation and Governance: Main Results of the OECD Development Centre Programme of Work 2001/2002, Paris: OECD, May. 
Oman, Charles and Christiane Arndt (2006), Uses and Abuses of Governance Indicators, Paris: OECD Development Centre

Parteka A. (2007), Employment and export specialisation patterns versus GDP per capita performance: unifying approach. Università Politecnica delle Marche, Quaderno di Ricerca (Working Paper) 302 (downloadable from http://www.dea.univpm.it/quaderni/pdf/302.pdf).

Parteka, Aleksandra and Massimo TamberI (2008), "What Determines the degree of Export Diversification, mimeo of paper presented in the European Trade Study Group conference in Warsaw, 11-13 September 2008.

Persson, Torsten and Guido Tabellini (2006), “Democratic capital the nexus of political and economic change”, NBER Working Paper No. 12175.

Pires, Pedro (2010), Discurso proferido por Sua Excelencia o Senhor Presidente da Republica de Cabo Verde na Cerimonia de Atribuicao do Grau de Doutor Honoris Causa pela Universidade Tecnica de Lisboa, June.

Plane (1997), "Privatization and economic growth: Reflections and observations” In H. Giersch (Ed.), Privatization at the end of the century. Germany: Springer.

PNUD (2004), “La Situation du Développement Humain au Cap Vert”, Rapport national sur le développement humain, United Nations.

Przeworski, Adam, M. Alvarez, J.A. Cheibub and F. Limongi (2000), Democracy and Development: Political Institutions and Well-Being in the World, 1950-1990, Cambridge: Cambridge University Press.

Przeworski Adam and Fernando Limongi (1993), "Political regimes and economic growth.”, The Journal of Economic Perspectives, 7, pp. 51-69. 
Reinhart, Carmen and Kenneth Rogoff (2009), This time is different: eight centuries of financial folly, Princeton University Press, Princeton.

Remmer (1990), Democracy and economic crisis: The Latin American Experience. World Politics, 42, pp. 315-335.

Ribeiro, Ana Paula, João Loureiro and Manuel M. F. Martins (2008), Assessment of the Exchange Rate Cooperation Agreement Cape Verde-Portugal, Ministry of Finance, October

Rodrik, D. (2005), “Policies for Economic Diversification.” CEPAL Review 87, pp. 7-23.

Santos, Vanda (2010), Post-colonial Cape Verdean culture as a contributor to a culture of peace, presentation to African Development Successes course module, FEUNL based on Ph.D dissertation presented to Universitat Jaume I, "La cultura postcolonial en Cabo Verde como aporte a una cultura de paz”.

Tibana, Roberto J. The composite indicator of economic activity in Mozambique (ICAE): Filling in the knowledge gaps to enhance public-private partnership (PPP), OECD Development Centre Working Paper n²27, November 2003.

United Nations Department of Economic and Social Affairs (2008), Trends in Sustainable Development: Africa Report, United Nations: New York.

Werlin (1996), “Cape Verde: Emerging Tourist Destination”, George Washington University, 1996.

World Bank (2009), World Development Indicators, World Bank: Washington, D.C.

Young (1998), Africa: An interim balance sheet. In P. Lewis (Ed.), “Africa: Dilemmas of development and change” .Boulder: Westview Press. 